\title{
Use of nanotechnology in combating coronavirus
}

\author{
Saee Gharpure ${ }^{1} \cdot$ Balaprasad Ankamwar ${ }^{1}[$
}

Received: 12 December 2020 / Accepted: 19 June 2021 / Published online: 28 June 2021

(c) King Abdulaziz City for Science and Technology 2021

\begin{abstract}
Recent COVID-19 pandemic situation caused due to the novel severe acute respiratory syndrome coronavirus 2 (SARS$\mathrm{CoV}-2$ ) affected global health as well as economics. There is global attention on prevention, diagnosis as well as treatment of COVID-19 infection which would help in easing the current situation. The use of nanotechnology and nanomedicine has been considered to be promising due to its excellent potential in managing various medical issues such as viruses which is a major threat. Nanoparticles have shown great potential in various biomedical applications and can prove to be of great use in antiviral therapy, especially over other conventional antiviral agents. This review focusses on the pathophysiology of SARS-CoV-2 and the progression of the COVID-19 disease followed by currently available treatments for the same. Use of nanotechnology has been elaborated by exploiting various nanoparticles like metal and metal oxide nanoparticles, carbonbased nanoparticles, quantum dots, polymeric nanoparticles as well as lipid-based nanoparticles along with its mechanism of action against viruses which can prove to be beneficial in COVID-19 therapeutics. However, it needs to be considered that use of these nanotechnology-based approaches in COVID-19 therapeutics only aids the human immunity in fighting the infection. The main function is performed by the immune system in combatting any infection.
\end{abstract}

Keywords SARS-CoV-2 $\cdot$ COVID-19 disease $\cdot$ Coronavirus $\cdot$ Nanotechnology $\cdot$ Antiviral properties

\section{Introduction}

Infectious diseases, also called as communicable disease, are those which spread directly or with the help of any medium indirectly by causative agents such as bacteria, fungi, viruses, protozoa, parasites, etc. Viruses are known to affect different cells, tissues and organs upon infection, which can even lead to death in severe cases (Singh et al. 2017; Chen and Liang 2020). Till date, viral diseases have accounted for hundreds of deaths world-wide thereby posing a threat of human health as well as global economy (Mehendale et al. 2013). Viruses have accounted for several outbreaks in recent times. Different viruses such as Ebola, Zika, Nipah, influenza, Chikungunya, coronavirus, etc., have contributed to alarming mortalities worldwide. One such example is the outbreak of the coronavirus disease which started spreading in late 2019 (COVID-19). The COVID-19 outbreak

Balaprasad Ankamwar

bankamwar@yahoo.com

1 Bio-Inspired Materials Research Laboratory, Department of Chemistry, Savitribai Phule Pune University (Formerly University of Pune), Ganeshkhind, Pune 411007, India was initiated from Wuhan, present in the Hubei Province of China. The causative agent of the COVID-19 disease has been identified to be severe acute respiratory syndrome causing novel coronavirus 2 (SARS-CoV-2) which propagates through eyes, nose and mouth (Gurunathan et al. 2020; Nikaeen et al. 2020). COVID-19 disease outbreak has been declared to be a pandemic by the World Health Organization (WHO) in March 2020 with incidence of 55,510,763 confirmed cases and 1,335,191 deaths worldwide as on 17th November 2020. The worldwide impact of this pandemic is scary and it might worsen further until medicines or vaccines specifically targeting the COVID-19 disease come into market (Chauhan et al. 2020; Campos et al. 2020).

The Coronaviridae family, commonly called as coronaviruses, consists of single stranded RNA viruses which can infect mammals as well as birds. These RNA viruses consist of membrane with spike-shaped transmembrane glycoproteins which encapsulate the viral genome. Coronaviruses get their name from the protein spikes of club shape present upon their outer membrane and are further divided into four classes, i.e., $\alpha, \beta, \gamma$ and $\delta$ coronaviruses. The recent COVID-19 pandemic has arisen on account of $\beta$ type of coronaviruses which also include viruses causing severe 
acute respiratory syndrome (SARS) as well as Middle East respiratory syndrome (MERS) (Song et al. 2019; Zhou et al. 2020a). The frequently occurring indications of the COVID19 disease are dry cough, fever, breathing trouble, fatigue, etc., whereas symptoms like headache, sore throat, loss of appetite, diarrhea, body pain, etc., are the lesser common ones. The SARS-CoV-2 further results in viral pneumonia as well as acute respiratory distress syndrome (ARDS) in most severe cases accounting for inflammation, oxidative stress as well as aggravated immune response which might further lead to death due to associated co-morbidities like hypertension, heart diseases as well as diabetes (Weiss et al. 2020). Amongst confirmed COVID-19 cases, $80 \%$ of the affected patients show only mild symptoms while the remaining patients display moderate to severe symptoms which might require medical attention. Even though symptoms of hospitalized patients may appear to be moderate in initial phases, they may escalate further causing hypoxic conditions followed by ARDS which then requires intensive care with artificial ventilation. The progression of COVID19 disease triggers inflammation in a progressive manner which may excessively activate coagulation leading to complications (Mehta et al. 2020; Zheng et al. 2020a). Patients have reported severe damage to several vital organs like heart, kidney, liver, gastro-intestinal tract, central nervous system associated with COVID-19 which may progress into multi-organ complications ultimately causing death in severe cases (Zheng et al. 2020b).

In the current pandemic situation, there are two things of prime concern crucial for controlling the situation; one is decreasing the rate of infection and other is increasing the rate of recovery. The world is focusing on development of COVID-19 vaccines as well as therapeutic drugs so as bring this pandemic under control as soon as possible. The presence of 63 candidate vaccines already under clinical studies along with 172 candidates under preclinical development has been reported by the WHO as on January 5, 2021 (Kyriakidis et al. 2021). Most of these vaccines are inactivated or live attenuated viral vaccines, recombinant vaccines, DNAbased vaccines or messenger RNA (mRNA)-based vaccines (Tang et al. 2020; Kaur and Gupta 2020). Some of these COVID-19 vaccines which have received emergency use authorization in these pandemic times have been developed by Oxford/AstraZeneca (UK) (Covishield), Johnson and Johnson (USA) (JNJ-78436735/Ad26.COV2.S), Gamaleya Research Institute (Russia) (Sputnik V), Bharat Biotech (India) (Covaxin), SinoVac (China) (CoronaVac), Sinopharm (China) and others (Khurana et al. 2021). These are typically inactivated or live attenuated viral vaccines with associated merits like strong immune response as well as easy storage. However, there are associated demerits as well which include problems during large-scale production, high cost and requirement of booster doses for development of required immunity levels (Bouazzaoui et al. 2021). These disadvantages have been overcome using mRNA-based vaccines developed by Pfizer/BioNTech/Fosun Pharma (mRNA-BNT162b2/Comirnaty) and Moderna/US NIAID (mRNA-1273) which were approved for EUA due to its efficiency in maintaining mRNA stability as well as high levels of targeted delivery in the host cell (Thi et al. 2021). These mRNA-based vaccines have used lipid nanoparticles as carrier molecules thus underlining the importance of nanotechnology in vaccine development. Also, there several therapeutic drugs which are being developed specifically targeting SARS-CoV-2, but those are still under clinical studies (Al-Horani et al. 2020).

The present treatment of the COVID-19 disease is purely symptomatic as it includes broad spectrum antivirals and antibiotics which treat secondary infections as well as corticosteroids to control inflammatory responses which can only manage mild to moderate symptoms (Kumar and Rathi 2020). However, there is need for development of specific therapy for targeting the COVID-19 disease. Various upcoming therapeutics employed to control COVID-19 infection specifically target viral entry, replication, different vital enzymes like RNA polymerase, protease, etc., along with involvement of nanotechnology-based drug delivery systems. Various antiviral therapies have been efficiently designed using concepts of nanotechnology due to multifaceted nature of nanoparticles aiding in various biomedical applications (Agarwal et al. 2017; Chhikara et al. 2020). The already established nano-delivery systems can be used for combating COVID-19 with high efficacy using therapeutic drugs and vaccines specific to SARS-CoV-2. Hence, there is need to access the use of nanotechnology for management of COVID-19 pandemic for developing drugs/vaccines specific against SARS-CoV-2 (Abdul et al. 2020). Herein, this review focusses on pathophysiology of SARS-CoV-2, available treatments present in COVID-19 therapeutics and role of nanotechnology in improving these treatments thus efficiently combatting SARS-CoV-2 infection.

\section{Life cycle and pathology of SARS-CoV-2}

SARS-CoV-2 is a novel RNA virus having single stranded RNA of length $34 \mathrm{~kb}$ as the genetic material surrounded by nucleocapsid with helical symmetry having $80 \%$ similarity with the SARS-CoV as well as $96 \%$ similarity with the BatCoV RaTG13 (Zhou et al. 2020a). The morphological characteristics of the novel SARS-CoV-2 have been elucidated with the help of electron microscopy. SARS-CoV-2 has been observed to show coronavirus-specific structure with viral particles within the size range $70-90 \mathrm{~nm}$ which have been found in various intracellular organelles or membrane vesicles. There are multiple speculations stating structural 
similarities in SARS-CoV and SARS-CoV-2 because of immense similarities in their genetic sequences. The morphology of SARS-CoV-2 has been depicted in Fig. 1. Different viral structural proteins have been embedded into the lipid bilayer derived from the host cell surrounding the nucleocapsid along with the viral genetic material. The viral genome encodes for 29 proteins which are subdivided into 4 structural proteins, 9 accessory proteins as well as 16 non-structural proteins (Astuti and Ysrafil 2020; Khailany et al. 2020). The four viral structural proteins include the spike glycoprotein (S protein) involved in attachment of the virus with the host cell receptor, membrane protein (M protein) involved in maintaining viral membrane integrity, nucleocapsid protein ( $\mathrm{N}$ protein) associated with the viral RNA genome and the envelope protein (E protein) which provides structural assembly surrounding the viral genome The spike protein has driven a lot of focus due to its important role in receptor binding as membrane fusion thereby leading to viral entry into the host cell because of which it has been a target molecule for neutralizing SARS-CoV-2. There are three subunits forming the $\mathrm{S}$ protein which get separated to form $\mathrm{S}$ monomers upon action of host cell proteases which are critical for viral infection. (Tooze et al. 1984; de Haan and Rottier 2005; Liu et al. 2014; Masters 2006; Chen et al. 2020). Apart of structural proteins, there are cellular proteases such as trypsin, trypsin-like proteases, cathepsin L, plasmin, furin, transmembrane protease serine 2 (TMPRSS2), etc., involved in viral ingress followed by its penetration into the host cells.

The genome similarities between SARS, MERS and the novel SARS-CoV-2 contribute to the similar nature of their infection mechanisms using the same host receptor angiotensin converting enzyme 2 (ACE2). The progression of the SARS-CoV-2 infection into the human host cell has been well represented in Fig. 2 (Bertram et al. 2011). The

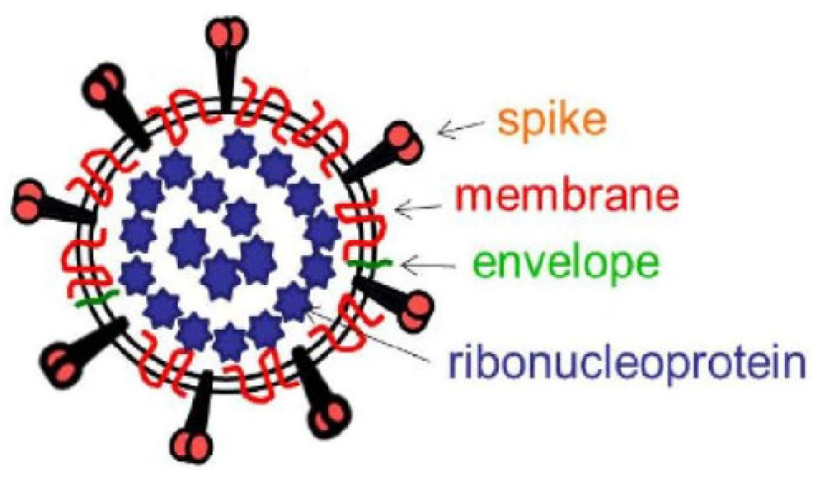

Fig. 1 Schematic representation of structural characteristics of SARS-CoV-2 Reprinted with permission from Chen et al. (2020) Application prospect of polysaccharides in the development of antinovel coronavirus drugs and vaccines. Int J Biol Macromol 164:331343. Copyright@ Elsevier infiltration of coronaviruses into the host cells is governed by interaction of the viral spike protein with the host cell receptor along with its priming using host cell proteases. Similar to SARS-CoV, SARS-CoV-2 also utilized ACE2 receptor in the host cell so as to internalize the viral particles as well as host cell-specific TMPRSS2 serine proteases which are used for $\mathrm{S}$ protein priming. S protein of SARSCoV-2 is involved in attachment of the viral particles with the human host cells with subsequent membrane fusion of the host and the virus. S protein associates with the host cell through the membrane-bounded receptor, angiotensin converting enzyme 2 (ACE2) which is abundantly expressed in respiratory cells, macrophages as well as monocytes ( $\mathrm{Lu}$ et al. 2020; Wrapp et al. 2020). The S protein includes two subunits which play important role in pathophysiology of SARS-CoV-2. The first S1 subunit is associated with receptor binding whereas the other $\mathrm{S} 2$ subunit is associated with membrane fusion of the host and the virus which is crucial for viral infection (Simmons et al. 2004; Song et al. 2018; Li et al. 2005). Once $S 1$ subunit present in the $S$ protein binds with the ACE2 receptor, SARS-CoV-2 enters into the human host cell via clathrin-mediated endocytosis following which $\mathrm{S} 2$ subunit present in the $\mathrm{S}$ protein is cleaved by furin protease thereby activating the S protein (Yang and Shen 2020; Hoffmann et al. 2020a). Membrane fusion of the virus and the host cells is triggered following action of cathepsin L in the endolysosome thereby releasing viral RNA. Alternatively, the S protein-ACE2 receptor complex can also enter the host cell through direct membrane fusion following its activation by transmembrane protease serine 2 (TMPRSS2) ultimately resulting in release of viral RNA. Once the viral RNA enters the host cell environment, viral genome replication and synthesis of nucleocapsid protein takes place in the cytoplasm whereas other structural proteins such as envelope protein, spike protein and the membrane protein are synthesized in the endoplasmic reticulum (ER) which is further carried to the Golgi apparatus. Assembly of viral genome along with $\mathrm{N}$ protein and the $\mathrm{S}, \mathrm{M}$ and $\mathrm{E}$ protein takes place in the ER-Golgi intermediate compartment (ERGIC) following which viral particles are assembled and released. The progression of viral infection leads to symptoms like inflammation, coagulopathy, hypoxia, etc. (Hoffmann et al. 2020b; Liu et al. 2020b).

\section{Treatment of COVID-19}

Currently, therapeutic drugs specifically targeting SARS$\mathrm{CoV}-2$ are still under clinical studies. Due to lack of medication which would specifically target SARS-CoV-2, the existing therapy employed in COVID-19 treatment includes use of immunomodulatory drugs and broad spectrum antiviral drugs such as neuraminidase inhibitors, RNA synthesis

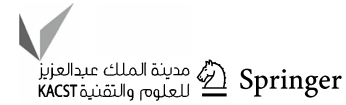




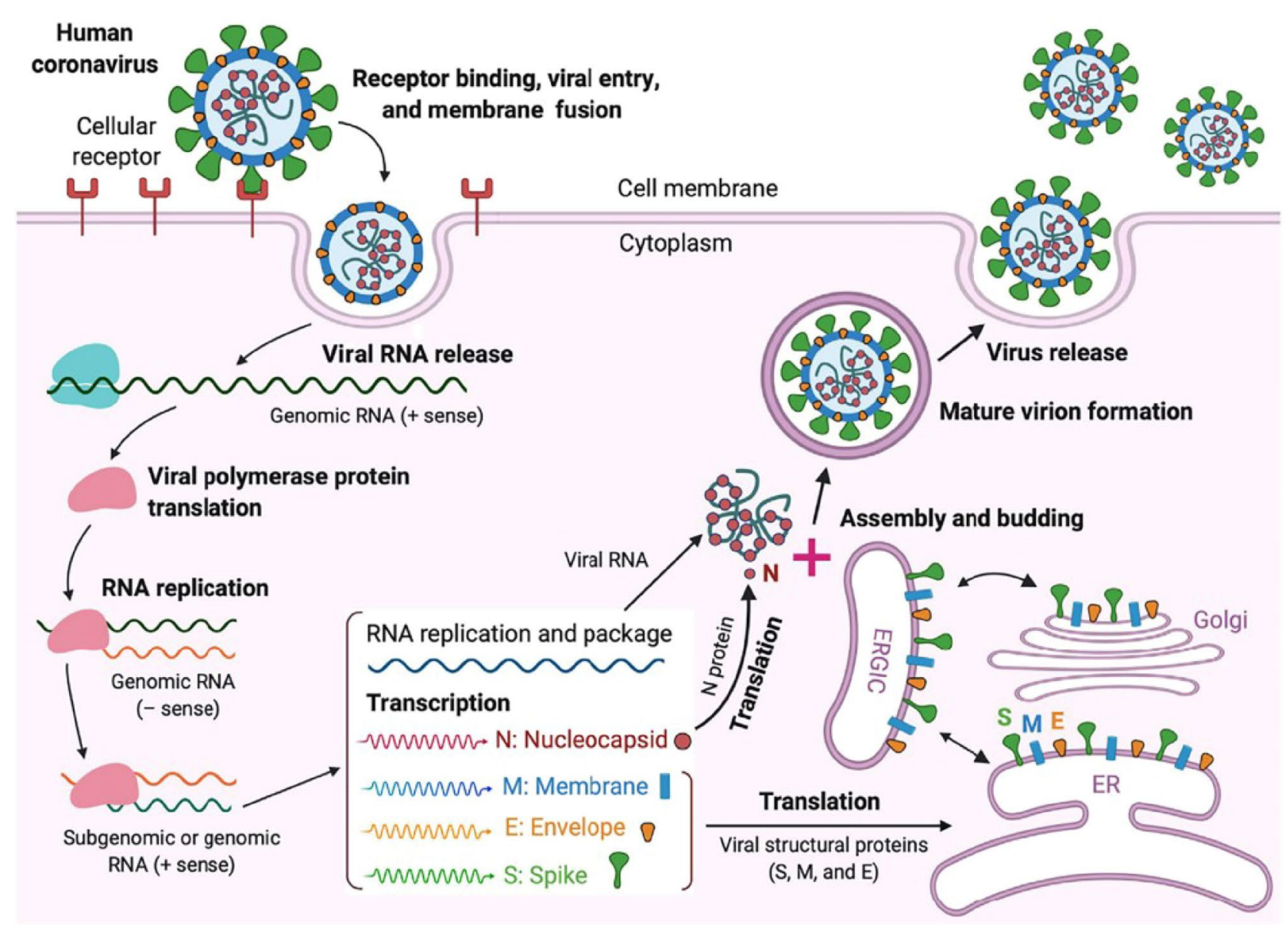

Fig. 2 Pathophysiology of SARS-CoV-2 and its mode of infection in human host cells Reprinted with permission from Chen et al. (2020) Application prospect of polysaccharides in the development of anti- novel coronavirus drugs and vaccines. Int J Biol Macromol 164:331343. Copyright@Elsevier

and hence is a better option than chloroquine (Liu et al. 2020a; Aguiar et al. 2018). Ivermectin, which is an antiparasitic drug known to inhibit RNA replication along with decreasing RNA load, has been observed to show positive results for treating COVID-19 patients (Caly et al. 2020). In the current pandemic situation, any therapeutic drug which acts upon one or more cellular events leading to weakening of the virus thus limiting its propagation within the host cells is being used to control further propagation of the COVID19 disease.

However, use of broad spectrum antiviral agents and immunomodulatory agents exhibit lack of specificity and can be cytotoxic towards host cells. In case of most therapeutic drugs used against COVID-19, there is still need for better understanding about its biosafety as well as efficacy. The side effects that the use of this antiviral therapy would cause are also not fully understood. Hence, case by case evaluation of antiviral therapy is necessary so as to understand its cross-reactivity in patients (Cardoso et al. 2020). Considering all these shortcomings, there is need for development higher efficacy and lower cytotoxicity in affected patients 
of alternative therapeutics which would be safe, tunable, target-specific, biocompatible, cost-effective, etc., for efficient treatment of diseases like COVID-19 (Gurunathan et al. 2020). The use of nanotechnology in this regard can prove to be a boon considering its applications in prevention, detection as well as treatment of COVID-19 disease.

\section{Use of nanotechnology for treating COVID-19}

Nanotechnology deals with design and manipulation of materials within the size range $1-100 \mathrm{~nm}$. Nanotechnology comprises of synthesis and application of different nanomaterials which have been observed to show unique physical, chemical, mechanical, optical as well as electronic properties in comparison with their bulkier counterparts and hence show their applications in various fields like cosmetics, agriculture, textiles, construction, environmental remediation, electronics, biomedicine, etc. (Gharpure et al. 2019a, b; Gharpure and Ankamwar 2020). Biological applications of nanomaterials include its use in bio-sensing, bio-imaging, drug delivery, therapy, detection, regenerative medicine, antimicrobial agents, etc., by virtue of various properties like high surface area to volume ratio, biocompatible nature, catalytic efficacy, antioxidant potential, easy functionalization, etc. Due to its multi-faceted nature, nanoparticles have been extensively used in prevention, detection, therapy as well as control of several infectious diseases (Kirtiwar et al. 2018; Ankamwar and Gharpure 2019). Likewise, nanotechnology-based approaches hold a lot of potential which needs to be exploited for management of the COVID-19 pandemic. Nanotechnology can offer favorable options to be used for prevention, diagnosis as well as treatment of COVID-19 disease (Valdiglesias and Laffon 2020).

The strategies for combating SARS-CoV-2 and dealing with COVID-19 disease using nanotechnology-based approaches make use of nanomaterials as carrier systems and/or adjuvants in development of potential vaccine candidates under clinical evaluation. It also exploits nanomaterials as carrier systems for drug delivery and/or nano-encapsulation using some active components for targeted release to be used in therapeutic applications (Nikaeen et al. 2020; Sivasankarapillai et al. 2020). The use of nanotechnology in treatment of COVID-19 disease focusses upon inhibiting one or more viral processes like interaction of viral particles with host cell, fusion of both the viral and host cell membranes, viral protein synthesis, viral genome replication, etc. (Mainardes and Diedrich 2020). Some of the most commonly used nanoparticles for antiviral therapy include metal and metal oxide nanoparticles, carbon-based nanoparticles, quantum dots, polymeric nanoparticles as well as lipid-based nanoparticles which have been already known for their antimicrobial, antiviral as well as drug delivery applications. With the help of these nanoparticles, COVID19 pandemic can be managed by development of personal protective equipment (PPE) with high level of infection protection as well as effective anti-viral disinfectants so as to inactivate the virus thereby controlling its propagation, development of diagnostic tools for effective recognition of SARS-CoV-2 which are easy to use, less time consuming, reliable and cost effective, development of therapeutic drugs for treating COVID-19 disease with low cytotoxicity, high specificity and efficacy as well as development of an efficient vaccine to boost immunity to fight the infection without causing any side effects. Here, we will focus upon use of different types of nanoparticles as well as antiviral agents contributing to high biocompatibility, increased efficacy as well as high specificity to be used in COVID-19 therapeutics.

\section{Metal and metal oxide nanoparticles}

The multi-faceted nature of nanoparticles have a lot of potential in aiding management of COVID-19 pandemic through development of strategies for prevention, diagnosis, treatment as well as vaccine development of the COVID-19 disease (Chan 2020). Metal and metal oxide nanoparticles possess a lot of potential of COVID-19 management by virtue of their multi-faceted properties like increased surface area to volume ratio, ease of synthesis, tunable size and morphology, surface chemistry, easy functionalization, high biocompatibility, etc. (Shankar et al. 2004; Ankamwar et al. 2016; Ankamwar 2020). Different metal-based nanoparticles have already been reported to show antiviral properties against various viruses such as influenza virus, hepatitis B virus (HBV), herpes simplex virus, human immunodeficiency virus (HIV), monkeypox virus, etc., and hence their applicability can be extrapolated in COVID-19 therapeutics (Galdiero et al. 2011). These antiviral attributes of metal and metal oxide nanoparticles are dependent primarily upon their physico-chemical properties which in turn influence their loading capacity, neutralization potential as well as efficacy of membrane penetration and membrane fusion. In addition to this, these nanoparticles mimic living cells thus enabling fusion of nanoparticles with the viruses. These nanoparticles also act as carrier systems for targeted drug delivery in a controlled manner along with improved loading capacity, bio-availability, retention times as well as drug stability because of which they can be preferred over traditional antibiotics (Singh et al. 2017). Antiviral therapies make use of metal nanoparticles like gold, silver, copper, zinc, etc., in addition to metal oxide nanoparticles like iron oxide, zinc oxide, silica, titanium dioxide, etc., due to its antiviral properties as elaborated in Table 1 (Chen and Liang

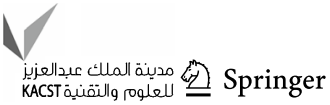


Table 1 Antiviral properties of metal and metal oxide nanoparticles

\begin{tabular}{|c|c|c|c|}
\hline Nanoparticles & Virus & Mode of action & References \\
\hline $\begin{array}{l}\text { Polysaccharide-coated silver nano- } \\
\text { particles }\end{array}$ & Monkeypox virus & $\begin{array}{l}\text { Inhibition of host cell binding and/or } \\
\text { disruption of host cell biochemical } \\
\text { pathways }\end{array}$ & Rogers et al. (2008) \\
\hline Silver nanoparticles & Murine norovirus & $\begin{array}{l}\text { Interaction of } \mathrm{Ag}^{0} \text { with the thiol } \\
\text { groups of the murine norovirus-1 } \\
\text { protein capsid, making the RNA } \\
\text { accessible }\end{array}$ & Gusseme et al. (2010) \\
\hline $\begin{array}{l}\text { Polyvinylpyrrolidone-coated silver } \\
\text { nanoparticles, bovine serum albu- } \\
\text { min-coated silver nanoparticles }\end{array}$ & Human immunodeficiency virus & $\begin{array}{l}\text { Preferential binding with the gp } 120 \\
\text { subunit of the viral envelope } \\
\text { glycoprotein inhibit the virus from } \\
\text { binding to host cells }\end{array}$ & Elechiguerra et al. (2005) \\
\hline $\begin{array}{l}\text { Polyvinylpyrrolidone-coated silver } \\
\text { nanoparticles }\end{array}$ & $\begin{array}{l}\text { Severe acute respiratory syndrome } \\
\text { coronavirus } 2\end{array}$ & $\begin{array}{l}\text { Interference with viral entry into the } \\
\text { host cell }\end{array}$ & Jeremiah et al. (2020) \\
\hline $\begin{array}{l}\text { Sialic-acid-functionalized gold nano- } \\
\text { particles }\end{array}$ & Influenza virus & $\begin{array}{l}\text { Interference with interaction of virus } \\
\text { and host cell thereby inhibiting } \\
\text { viral entry }\end{array}$ & Papp et al. (2010) \\
\hline $\begin{array}{l}\text { Multi-sufonated ligand functional- } \\
\text { ized gold nanoparticles }\end{array}$ & Dengue virus & $\begin{array}{l}\text { Binding with viral envelope protein } \\
\text { inhibits viral interaction with the } \\
\text { host cell }\end{array}$ & Zacheo et al. (2020) \\
\hline Copper nanoparticles & Herpes simplex virus & $\begin{array}{l}\text { Increase in ROS production caus- } \\
\text { ing oxidative damage to the viral } \\
\text { genome }\end{array}$ & Sagripanti et al. (1993) \\
\hline Copper nanoparticles & Human coronavirus $229 \mathrm{E}$ & $\begin{array}{l}\text { Destruction of the viral RNA and } \\
\text { irreversible damage to viral enve- } \\
\text { lope protein and spike protein }\end{array}$ & Warnes et al. (2015) \\
\hline Copper nanoparticles & $\begin{array}{l}\text { Severe acute respiratory syndrome } \\
\text { coronavirus } 1\end{array}$ & $\begin{array}{l}\mathrm{Cu}^{2+} \text { ions irreversibly damage viral } \\
\text { proteins and lipids along with ROS } \\
\text { generation causing viral inactiva- } \\
\text { tion }\end{array}$ & van Doremalen et al. (2020) \\
\hline Zinc oxide nanoparticles & Herpes simplex virus 2 & $\begin{array}{l}\text { Blockage of viral entry into the host } \\
\text { cells }\end{array}$ & Antoine et al. (2016) \\
\hline Zinc oxide nanoparticles & Nidovirus & $\mathrm{Cu}^{2+}$ interferes with viral replication & Ishida (2019) \\
\hline Iron oxide nanoparticles & MS 2 coliphage & $\begin{array}{l}\text { Direct interaction with viral particles } \\
\text { leads to its inactivation }\end{array}$ & Kim et al. (2011) \\
\hline $\begin{array}{l}\text { Superparamagnetic iron oxide } \\
\text { nanoparticles }\end{array}$ & $\begin{array}{l}\text { MS2 bacteriophage, Herpes simplex } \\
\text { virus, Viral hemorrhagic septicae- } \\
\text { mia virus, Infectious pancreatic } \\
\text { necrosis virus }\end{array}$ & $\begin{array}{l}\text { Irreversible damage to the viral } \\
\text { genome and inhibition of viral } \\
\text { genome replication }\end{array}$ & Bromberg et al. (2012) \\
\hline
\end{tabular}

2020). However, the exact mechanism responsible for their antiviral potential is not yet understood.

\section{Silver nanoparticles}

There are several reports which show antimicrobial, antiviral, anticancer, anti-inflammatory, anti-angiogenic and anti-coagulant properties of silver nanoparticles (AgNPs) by virtue of its unique characteristics (Gurunathan et al. 2018, 2020; Park et al. 2014). As AgNPs show antiviral potential without any surface functionalization, they have been looked at as a potential candidate to be used for inactivating SARS-CoV-2. There is a previous report which shows antiviral activity of bare AgNPs against monkeypox virus by prevention of internalization of viral particles. However, intrinsic cytotoxicity has been observed towards host cells which can be overcome through surface functionalization (Rogers et al. 2008; Elbaz et al. 2016). AgNPs shows high affinity with sulphur containing groups which explains its strong association with cysteine, methionine and glutathione which are usually present in active sites of several proteins. Thus presence of AgNPs might interfere with viral genome replication as well as protein synthesis due to inactivation of associated proteins thereby contributing to its antiviral potential. This antiviral mechanism of AgNPs has been demonstrated against bacteriophage MS2 as well as murine norovirus MNV1 (Zodrow et al. 2009; de Gusseme et al. 2010). Also, action of $\mathrm{Ag}_{2} \mathrm{~S}$ nanoclusters has been observed to inhibit replication of the viral RNA genome in porcine epidemic diarrhea virus (PEDV) in Vero cells which has 
been observed to be statistically significant ( $p$ value $<0.01$ ) As AgNPs show efficient antiviral activities against RNA viruses, it can be a probable candidate to be tested for inhibiting novel SARS-CoV-2 as well (Du et al. 2018). Association of AgNPs with the virus results in generation of reactive oxygen species on the surface of the nanoparticles which then results in disruption of the viral surface. This disruption of viral surface contributes to the antiviral potential of AgNPs.

AgNPs have also been observed to prevent physical association of the virus with the host cells thereby decreasing its infectivity thus contributing to their antiviral potential. Antiviral activity of AgNPs in a size-dependent manner has been observed in HIV-1 within the size range 1-10 nm where AgNPs around $10 \mathrm{~nm}$ were observed to show highest antiviral activity which was concluded to be its optimal size (Elechiguerra et al. 2005). In another study, antiviral activity of polyvinylpyrrolidone functionalized AgNPs has been depicted in a size dependent and dose dependent manner as demonstrated in Fig. 3. Two different cell lines, one of nonhuman origin (VeroE6/TMPRSS2) and other human lung epithelial cell line (Calu-3) were infected with SARS-CoV-2 at different viral concentrations measured as multiplicity of infection (MOI) and then were checked for cell viability and viral load after treatment with PVP-AgNPs. Cell viability was checked for infected VeroE6/TMPRSS2 to calculate the proportion of cells killed by the virus. The amount of viral load present in Calu-3 cells was further quantified using real time reverse transcriptase quantitative polymerase chain reaction (RT-qPCR). PVP-AgNPs were observed to show significant antiviral effect denoted by increase in viability of infected VeroE6/TMPRSS2 cells at concentrations within the range $1-10 \mathrm{ppm}$ in triplicate testing ( $p$ value $<0.005$ ). Similarly, Calu-3 cells showed remarkable decrease in viral load after treatment with silver nanoparticles within the same concentration range in triplicates with $p$ value $<0.001$. Effect of size on antiviral properties of AgNPs was tested by virus pre-treatment assay using AgNPs with sizes ranging from 2 to $100 \mathrm{~nm}$. It was observed that AgNPs with size $2-15 \mathrm{~nm}$ show significant antiviral properties and hence AgNPs with size $10 \mathrm{~nm}$ were considered for further studies. PVP-AgNPs could also rescue VeroE6/TMPRSS2 cells already infected by the SARS-CoV-2 represented by increase in proportion of living cells as well as decrease in viral load. Thus, PVP-AgNPs have shown antiviral activities against SARS-CoV-2 probably by inhibiting viral ingress or inactivating viral particles via association with the viral particles at initial phases of infection. Thus, AgNPs have been observed to show antiviral activities against SARSCoV-2 by disruption of disulfide linkages between the ACE2 receptor and $S$ proteins which is critical for viral entry into the host cell. The mechanism behind antiviral properties of AgNPs might be destruction of these disulfide linkages or other intracellular mechanisms (Jeremiah et al. 2020).

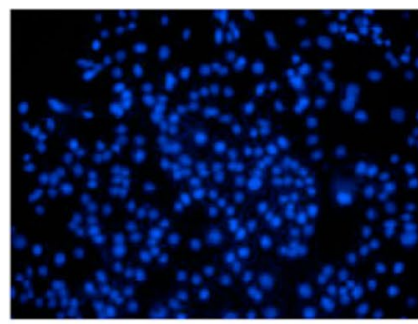

NC



Virus



AgNP10

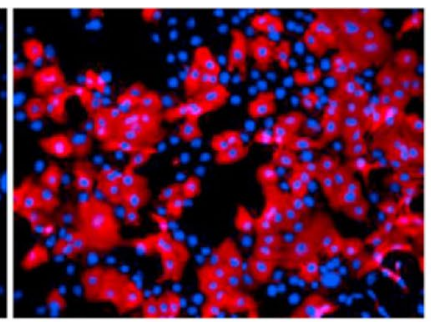

AgNP100

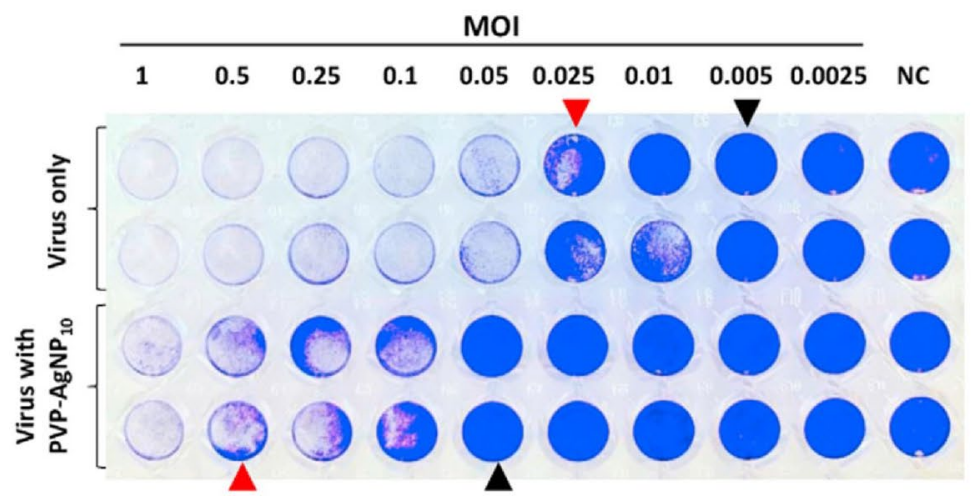

Fig. 3 Inhibitory effect of polyvinylpyrrolidone functionalized silver nanoparticles against SARS-CoV-2 in rescuing Vero/TMPRSS2 cells in size-dependent and dose-dependent manner Reprinted with permission from Jeremiah et al. (2020) Potent antiviral effect of silver nanoparticles on SARS-CoV-2. Biochem Biophys Res Commun 533:195-200. Copyright @ Elsevier 
Thus, AgNPs contribute to antiviral activities against various viruses by one of the three mechanisms, viz., attachment of AgNPs with the virus resulting failure in penetration into the host cells, association of AgNPs with the host cell membrane inhibits membrane fusion of the host cells with the viral particles and inhibition of viral genome replication (Rai et al. 2016).

\section{Gold nanoparticles}

Gold nanoparticles are extensively used for biomedical applications as a result of its associated unique properties such as surface chemistry, tunable size and shape, high biocompatibility, ease of synthesis, easy functionalization, etc. (Ankamwar and Gharpure 2019). Gold nanoparticles (AuNPs) have been widely used in detection and therapy of cancer, bacteria and viruses attributed to their antibacterial, antiviral as well as anticancer properties. Functionalized gold nanoparticles have been observed to exhibit enhanced antiviral properties especially against influenza virus, HIV as well as herpes simplex virus by virtue of multiple interactions between AuNPs and the viral particles (Bowman et al. 2008; Andresen et al. 2014). For example, the extent of inhibition that sialic acid functionalized AuNPs exhibits against influenza virus due to its multivalent interactions is higher in comparison with traditional antiviral agents like zanamavir thus proving to be a potential candidate to be used in antiviral therapy (Wen et al. 2009; Papp et al. 2010). Due to high affinity of AuNPs with thiol groups, sulfonated ligands have been frequently used for surface coating of AuNPs (Yang et al. 2015). There is a study which reports excellent antiviral potential through irreversible deformation of various viruses using AuNPs coated with mercaptoethanesulfonate (MES) in addition to mercaptoundecanesulfonic acid (MUS) as it disintegrates viral capsid structure due to multivalent interactions between the sulfonated AuNPs and the viral particles. Also, sulfonated ligands are known to mimic proteoglycans present on the host cell surface because of which the virus binds to the sulfonated AuNPs and the host cell is rescued from viral infection through competitive inhibition. These multivalent interactions of functionalized AuNPs with the virus can be used as a strategy for development of therapeutic agents to fight SARS-CoV-2 (Cagno et al. 2018; Baram-Pinto et al. 2010).

AuNPs coated with sulfonated polysaccharides have been reported to contribute to its antiviral properties. For example, sulfonated glucose and lactose-coated AuNPs have been reported to show promising antiviral activity against dengue virus (DENV). Docking experiments were used to confirm that varying ligand length is a crucial parameter in deciding antiviral properties of AuNPs. AuNPs with excellent antiviral potential were the one which perfectly fitted the $n$-octyl$\beta$-D-glucoside binding pocket of envelope protein present in
DENV. Thus, presence of surface ligands on AuNPs also influences its antiviral properties (Zacheo et al. 2020). In another study, similar results have been observed to inhibit interaction between MERS envelope and host cell membrane as represented in Fig. 4. S2 protein in MERS virus, a subunit of $S$ protein, which is responsible for viral envelope fusion to the host cell membrane consists of three domains, heptad repeat 1 (HR1), heptad repeat 2 (HR2), and fusion peptides (FP). Upon insertion of FP into the host cell membrane, HR1 and HR2 fuse to form 6-helix bundle (6-HB) which mediates fusion of viral envelope and host cell membrane thereby releasing viral genetic material into the host cell. An $\alpha$-helix peptide, pregnancy induced hypertension peptide (PIH), has been reported in this study which imitates HR2 by selective interaction with HR1 thereby preventing formation of 6-HB complex which ultimately results in preventing association between the virus and the host cell and selectively interact with HR1 to block the formation of 6-HB. PIH functionalized gold nanorods (PIH-AuNRs) have been assessed for their inhibitory effect with the help of cell fusion model. PIH-AuNRs were observed to completely inhibit fusion of viral envelope and the host cell membrane at the concentration of $1.0 \mu \mathrm{M}$ which was tenfold higher than only PIH in triplicate testing with $p$ value $<0.001$ which was statistically significant. Also, PIH was observed to be highly biocompatible when tested on biocompatibility and did not affect the cell viability on 293T, Huh-7, and L02 cells. Thus, PIH-AuNRs show tenfold increase in prevention of membrane fusion as compared to only PIH along with excellent biocompatibility and increased metabolic stability thereby proving to be an excellent alternative for MERS therapeutics (Huang et al. 2019). As peptide-functionalized AuNPs have been reported to show antiviral properties for treating MERS-CoV, similar approach can be undertaken in development of antiviral agents for inhibiting SARS-CoV-2 thereby treating COVID-19 disease.

Apart from use of AuNPs in antiviral therapy, they have also been used as nanocarriers for targeted release of traditional antiviral drugs thereby increasing efficiency of the antiviral treatment. The use of AuNPs as nanocarriers in antiviral therapy has been observed to increase its efficiency as compared to free antiviral agents, especially in case of retroviruses. The efficacy of AuNPs loaded with ribavirin was tested against measles virus on Vero cells against free ribavirin. There was significant increase in reduction of viral load by AuNPs loaded with ribavirin which was $78.1 \%$ as compared to free ribavirin which showed $25.4 \%$ reduction (Ahmed et al. 2020). In another study, AuNPs have been reported to be used as nano-carriers for delivery of the antiretroviral drug stavudine against HIV in human macrophage cells. The action of AuNPs-stavudine on macrophages results in pro-inflammatory activation which is an indicator of associated antiviral activity and hence can be 


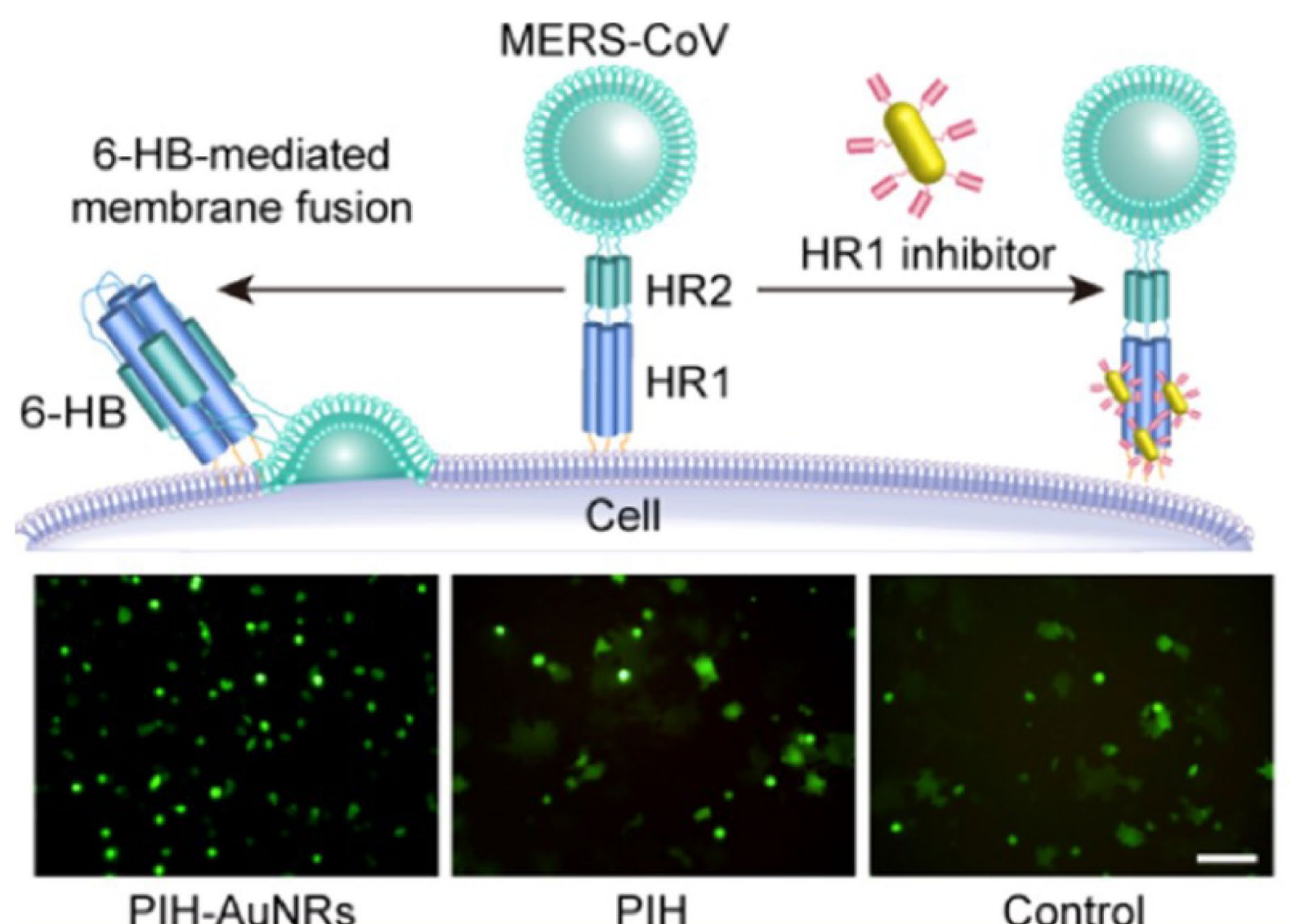

Fig. 4 Antiviral activity of pregnancy-induced hypertension (PIH) peptide functionalized gold nanorods by prevention of membrane fusion of Middle East respiratory syndrome coronavirus and host cells thereby inhibiting viral ingress Reprinted with permission from

considered as a promising candidate to be used in antiretroviral therapy (Zazo et al. 2017). This depicts that use of AuNPs increases the therapeutic potential of antiviral agents which can be exploited in COVID-19 therapeutics as well.

\section{Copper nanoparticles}

Copper is considered as an essential element required in trace amounts in human body for functioning and maintenance of immune system (Linder and Hazegh-Azam 1996). Presence of copper plays an inevitable role in functioning of various immune cells like natural killer cells, T cells, B cells, macrophages, monocytes, neutrophils, dendritic cells, etc., involved in killing infectious pathogens and elicitation of immune response through innate as well as adaptive immunity. Copper nanoparticles have been reported to exhibit antiviral potential against different viruses like human immunodeficiency virus, polio virus, influenza virus, retroviruses, etc. (Percival 1998; Koller et al. 1987). There are initial reports which elaborate use of copper in inactivation of poliovirus (Murray and Laband 1979). There are also
Huang et al. (2019) Novel gold nanorod-based HR1 peptide inhibitor for Middle East respiratory syndrome coronavirus. ACS Appl Mater Interfaces 11:19799-19807. Copyright @ American Chemical Society

reports showing antiviral properties of copper against Emiliania huxleyi virus 86 (EhV86) from the Phycodnaviridae family by disruption of its lytic cycle due to increase in production of reactive oxygen species (ROS). Copper nanoparticles dissociate into $\mathrm{Cu}^{2+}$ ions which increase ROS production thereby causing oxidative damage to the viral genome thus inhibiting herpes simplex virus (Sagripanti et al. 1993). Surfaces coated with copper have been observed to cause significant reduction in viral load in case of influenza A virus. This is because copper intercalates between the DNA strands which permanently damage the viral genome and hence it cannot replicate further thereby inhibiting the virus (Noyce et al. 2007).

Antiviral activity of copper against human coronavirus 229 (HuCoV 229) has been demonstrated by destruction of the viral RNA genome along with irreversible damage to the various structural proteins such as the envelope protein and the spike protein associated with the virus. HuCoV 229 has been observed to undergo irreversible inactivation in less than an hour on surfaces coated with a minimum of $70 \%$ copper or $\mathrm{Cu}-\mathrm{Ni}$ alloys which comprises of more than




90\% copper as compared to other smooth surfaces like Teflon, glass, stainless steel, ceramic tiles, polyvinyl chloride, etc., where the virus can stay in its infectious state for more the 6 days (Warnes et al. 2015; Kampf et al. 2020). Similarly, retention of SARS-CoV-1 as well as SARS-CoV-2 on copper containing surface was observed to be $\sim 4 \mathrm{~h}$ as compared to plastic and stainless steel where the virus persists of 24-48 $\mathrm{h}$ and cardboard where it can remain viable upto $24 \mathrm{~h}$. This occurs via action of $\mathrm{Cu}^{2+}$ ions on viral proteins and lipids which cause irreversible damage to viral protein along with ROS generation which results in inactivation of viral particles. Thus, use of copper containing alloys as surface disinfectants can inactivate SARS-CoV-2 thus helping in limiting the COVID-19 pandemic (van Doremalen et al. 2020). In addition to this, copper iodide nanoparticles have been reported to show antiviral properties when tested against H1N1 human influenza virus. Gold/copper sulphide core-shell nanostructures show varying antiviral properties against human norovirus ( $\mathrm{HuNoV}$ ) by irreversible damage to the nucleocapsid structure (Báez-Santos 2015). $\mathrm{Cu}^{2+}$ ions were observed to inhibit SARS-CoV-1 genome replication under in vitro conditions by inactivating papain-like proteases which are crucial for the viral replication process (Ishida 2018). Thus, similar approaches can be exploited to inactivate SARS-CoV-2 thereby enabling use of copper in COVID-19 therapeutics.

\section{Zinc oxide nanoparticles}

Zinc oxide nanoparticles ( $\mathrm{ZnO}$ NPs) are known to possess unique physico-chemical, opto-electronic as well as mechanical characteristics which have been exploited in various fields like textile, cosmetics, electronics, environmental remediation, biomedicine, catalysis, etc. (Gharpure and Ankamwar 2020; Mishra et al. 2017). ZnO NPs have been observed to show excellent antimicrobial (bacteria, fungi, viruses), anticancer, anti-inflammatory as well as anti-diabetic potentials which have been extensively applied in multiple areas of biomedicine (Gharpure et al. 2021a, b). ZnO has been listed as "generally recognized as safe" according to the United States Food and Drug Association (US-FDA) due to its biocompatible nature thereby increasing its use in biomedical applications (Rasmussen et al. 2010). Moreover, zinc is known to be a trace element in human body which is essential for crucial metabolic processes like protein synthesis, DNA/RNA synthesis, hemotopoesis, nerve development, etc., because of which administration of $\mathrm{ZnO}$ NPs is not a problem as these nanoparticles can be easily metabolized (Zhou et al. 2006; Jiang et al. 2018). In addition to this, there are several reports which show antiviral properties of zinc as well as influence of zinc in human body for antiviral immunity (Mishra et al. 2011). ZnO NPs have been observed to show antiviral properties against different viruses like influenza virus, rhinovirus, herpes simplex virus, etc. (Abdul et al. 2020). For example, $\mathrm{ZnO}$ tetrapods have been reported to show antiviral potential when tested against herpes simplex virus 2 (HSV-2) by blocking the entry of viral particles into the host cells like human vaginal epithelium as well as HeLa cells thereby inhibiting the spread of viral infection. $\mathrm{ZnO}$ tetrapods do so by neutralizing the viral particles thus contributing to significantly reduced infection rates (Antoine et al. 2016). In another study, comparative analysis of antiviral properties of ZnO NPs along with polyethylene glycol (PEG) coated ZnO NPs against H1N1 influenza virus have been reported. PEG coated $\mathrm{ZnO}$ NPs were observed to show enhanced antiviral potential as compared to bare $\mathrm{ZnO}$ NPs which was observed to be statistically significant ( $p$ value $<0.0001$ ). This may be due to reduced ROS generation and $\mathrm{Zn}^{2+}$ release because of surface coating, size reduction as well as easy diffusion of PEG coated ZnO NPs as compared to ZnO NPs. Thus, PEG-coated $\mathrm{ZnO} N \mathrm{NP}$ is a promising candidate to be used in antiviral therapy against H1N1 influenza virus (Ghaffari et al. 2019). Increase in intracellular $\mathrm{Zn}^{2+}$ concentration has been observed to inhibit viral genome replication of Nidovirus and other RNA viruses thereby inactivating the virus (Ishida 2019). As coronavirus is a RNA virus, $\mathrm{ZnO}$ NPs can prove as an effective antiviral agent to be used in COVID-19 therapeutics.

Additionally, zinc supplementation has been implemented to generate host resistance against SARS-CoV-2 infection by reducing the severity of symptoms by decreasing the viral load as a result of its antiviral potential (Eby 1997; Read et al. 2019; Razzaque 2020). This is because there are previous reports stating inhibitory effect of zinc on SARS-CoV replication. Use of zinc-based supplements has been observed to significantly reduce number of SARS-CoV by inactivation of RNA dependent RNA polymerase as well as proteolytic enzymes essential for viral genome replication (te Velthuis et al. 2010; Han et al. 2005; Hsu et al. 2004). However, since there is no concrete evidence, additional studies on SARS-CoV-2 are needed to confirm similar action of zinc on viral inactivation. In this COVID-19 pandemic, zinc supplementation has been used as an inexpensive adjunct therapy along with potential antiviral drugs to impart additional host resistance against SARS-CoV-2. This would require clinical validation, but using zinc in COVID-19 patients in the current situation would in turn serve as a well-intended trial (Rahman and Idid 2020). Using ZnO NPs would thus not only help in inactivation of SARS-CoV-2, but also boost antiviral immunity of the host by increasing the concentration of $\mathrm{Zn}^{2+}$ in the human body once these $\mathrm{ZnO}$ NPs are metabolized and hence can be considered to be used in COVID-19 therapeutics. 


\section{Iron oxide nanoparticles}

Iron oxide nanoparticles (IONPs) are extensively employed for various bio- applications like antimicrobial agents, drug delivery, cell separation, photo-thermal therapy, regenerative medicine, bio-imaging, etc., by virtue of their multi-faceted properties. Owing to its excellent magnetic properties, biocompatibility, stability, etc., different forms of IONPs such as magnetite $\left(\mathrm{Fe}_{3} \mathrm{O}_{4}\right)$, maghemite $\left(\gamma-\mathrm{Fe}_{3} \mathrm{O}_{4}\right)$ as well as hematite $\left(\alpha-\mathrm{Fe}_{3} \mathrm{O}_{4}\right)$ have been the most preferred amongst magnetic nanoparticles for various biomedical applications (Vallabani and Singh 2018). Activity of IONPs as antimicrobial, antiviral and anticancer agent is further enhanced by surface functionalization as it helps in modifying its physico-chemical characteristics, reduce ROS generation as well as preserves its magnetic properties thereby contributing to enhanced biocompatibility and colloidal stability (Arakha et al. 2015; Khalid et al. 2019). IONPs have been reported to enhance inactivation of MS2 bacteriophage thereby underlining its antiviral potential (Park et al. 2015). In another study, antiviral activity of superparamagnetic iron oxide nanoparticles (SPIONs) forming the core which is surrounded by silica nanoparticles attached to poly(hexamethylene biguanide) (PHMBG) or polyethyleneimine (PEI) have been reported. These biguanide or aziridine functionalized core-shell nanostructure inactivate several viruses such as MS2 bacteriophage, herpes simplex virus (HSV), viral hemorrhagic septicaemia virus (VHSV) as well as infectious pancreatic necrosis virus (IPNV) by causing irreversible damage to the viral genome as well as inhibiting viral genome replication along with easy separation due to associated magnetic properties of SPIONs thereby proving to be an excellent antiviral agent (Bromberg et al. 2012).

With the advent of COVID-19 pandemic, increasing attention has been paid to use of IONPs against SARS$\mathrm{CoV}-2$ infection. A molecular docking approach has been used to analyze interactions of $\mathrm{Fe}_{2} \mathrm{O}_{3}$ and $\mathrm{Fe}_{3} \mathrm{O}_{4}$ IONPs with the receptor binding domain which is a part of the spike protein (S1-RBD) present in SARS-CoV-2 which is involved in anchoring of the virus upon the host cell receptors These molecular docking analysis has revealed effective interactions of both $\mathrm{Fe}_{2} \mathrm{O}_{3}$ and $\mathrm{Fe}_{3} \mathrm{O}_{4}$ nanoparticles with the $\mathrm{S} 1-\mathrm{RBD}$ with $\mathrm{Fe}_{3} \mathrm{O}_{4}$ nanoparticles forming a more stable complex in comparison with $\mathrm{Fe}_{2} \mathrm{O}_{3}$ nanoparticles. The association of IONPs with SARSCoV-2 S1-RBD has been estimated to result in irreversible conformational changes thereby resulting in inactivation of the virus. However, in vivo studies need to be performed to confirm the antiviral activities of IONPs against SARS-CoV-2 (Abo-zeid et al. 2020). IONPs were found to effectively controlling H1N1 influenza virus pandemic due to its associated antiviral potential in a time and concentration dependent manner (Kumar et al. 2019).
Antiviral properties of iron oxide nanozymes have been represented in Fig. 5. Nanozymes are a new generation of artificial enzymes which has enzyme-like activities. However, they have an upper edge as compared to traditional enzymes as their enzyme activities can be enhanced by modulation of their physico-chemical properties like size, shape, surface charge, surface modification, etc. Iron oxide nanoparticles (IONPs) are one of the most commonly used nanozymes, called as iron oxide nanozymes (IONzymes), which have dual enzyme activities such as peroxidase and catalase activities. IONzymes with peroxidase activity have shown excellent antiviral activities against influenza A virus. Interaction of IONzymes with influenza A viruses showed considerable membrane damage to the viral envelope which was assessed using transmission electron microscopy. Also, hemagglutinin and matrix protein showed destruction, but nucleocapsid protein was unaffected. Due to the presence of transmembrane domains of both these proteins, they were observed to undergo destruction due to lipid peroxidation which was confirmed as purified hemagglutinin also showed significant damage upon action of IONzymes. These IONzymes cause peroxidation of lipids present in the viral lipid envelope followed by disintegration of the viral structural proteins further leading to inactivation of the virus. Efficiency of the IONzymes treated viral particles to infect the host cells was further tested using MDCK cells by examining attachment, proliferation and release of $\mathrm{H} 5 \mathrm{~N} 1$ viruses. IONzymes were observed to abolish the $\mathrm{H} 5 \mathrm{~N} 1$ viral infectivity against the host cells by hampering initial attachment and invasion in viral proliferation. Thus, treatment with IONzymes prevented the viral particles from infecting the host cells by interfering in the proliferation process thereby preventing its successive transmission as well (Qin et al. 2019). As Influenza A virus is a single stranded RNA virus similar to SARS-CoV-2, this approach can used for treatment of COVID-19 disease as well as prevention of its further transmission.

However, while using IONPs against SARS-CoV-2, there is need to consider associated complications in COVID-19 affected patients. COVID-19 patients have been frequently observed to show iron dysregulation. There are recent reports which depict association of SARS-CoV-2 spike protein along with haemoglobin $(\mathrm{Hb})$ via cell receptors such as CD147, CD26, etc., present on the erythrocyte as well as other blood cell precursors and ferroportin blockage due to hepcidin mimicking activity of the viral spike protein. These pathological conditions have resulted in decreased $\mathrm{Hb}$, increased iron load in cells and tissues as well as ferroptosis due to ROS generation and lipid peroxidation (Cavezzi et al. 2020). Thus, further increasing iron content in COVID-19 patients might intensify these complications which must be considered while using IONPs for COVID-19 therapeutics.

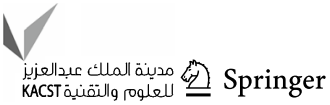




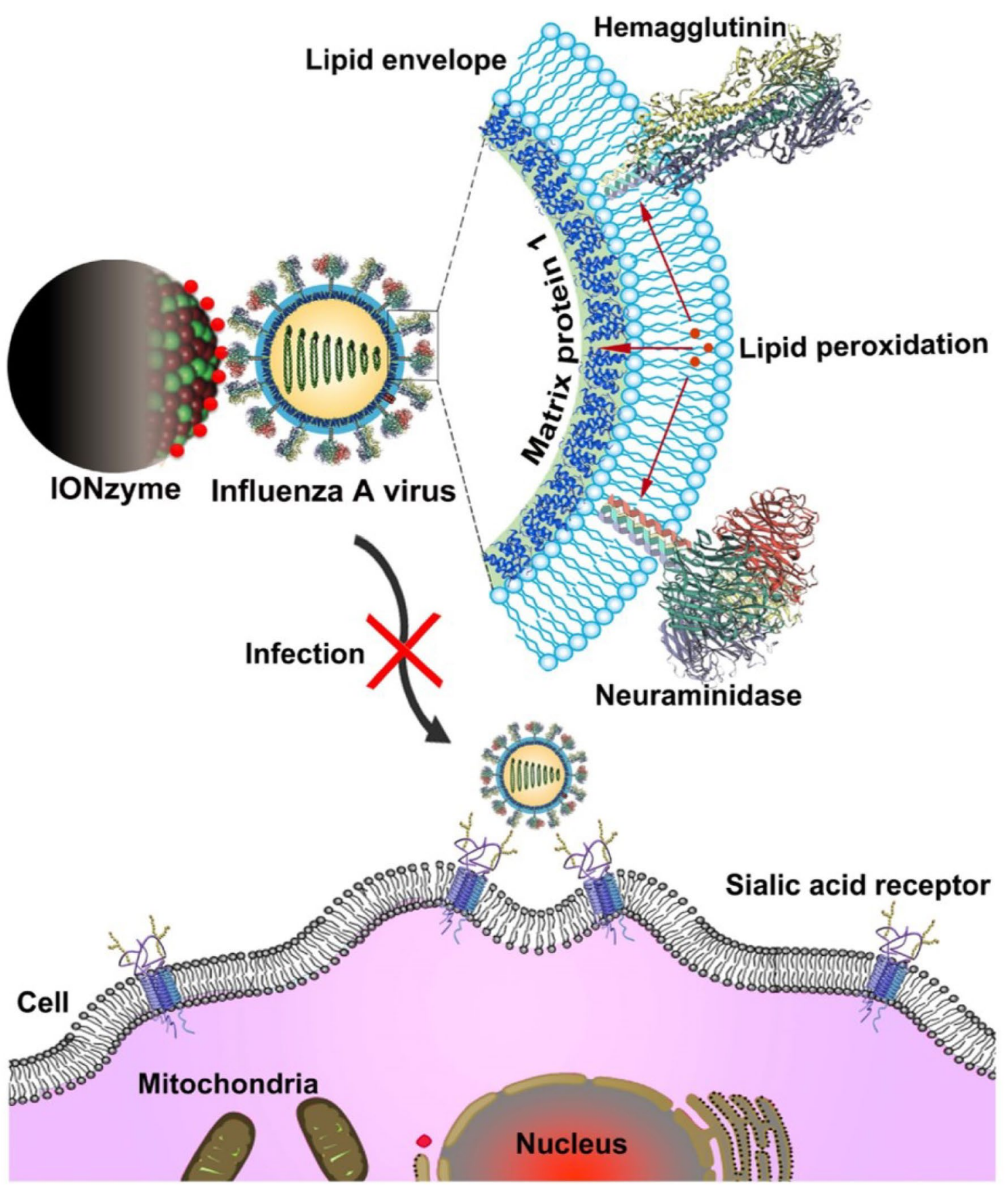

Fig. 5 Mechanism of inhibitory effect of iron oxide nanoparticlesbased nanozymes (IONzymes) against Influenza A virus leading to its transmission arrest Reprinted with permission from Qin et al. (2019)
Catalytic inactivation of influenza virus by iron oxide nanozyme. Theranostics 9:6920-6935. Copyright @ Ivyspring International Publishers

\section{Carbon-based nanoparticles}

Different carbon-based nanoparticles like carbon nanotubes (CNTs), graphene along with its derivatives, fullerenes, nanodiamonds, carbon quantum dots, etc., have been known for their extensive use in different fields like biomedicine, environmental remediation, electronic, smart devices, textile, wastewater treatment, etc., by virtue of their physico-chemical, opto-electronic, thermal and mechanical properties (Osman et al. 2020; Cui et al. 2018). Carbonbased nanoparticles have been extensively used for different bio-applications such as bio-imaging, drug delivery, disease theranostics, bio-sensing, antimicrobial agent, antiviral agent, anticancer agent, etc. (Maiti et al. 2019). The 
physico-chemical attributes of carbon-based nanoparticles like size, shape, surface charge, surface coating, etc., have been modulated depending upon the application for which it needs to be used. These nanoparticles have shown low cytotoxicity as well as high specificity in its antiviral properties and hence can be used for antiviral therapy acting via inactivation through direct contact, photocatalysis or mimetic action as elaborated in Table 2 (Innocenzi and Stagi 2020).

\section{Graphene and its derivatives}

Graphene is a two-dimensional planar sheet made of carbon atoms with $\mathrm{sp}^{2}$ hybridization which further undergoes surface modification to form its derivatives thereby showing easy surface modification, high biocompatibility and excellent dispersion. Graphene and its derivatives have shown high potential to be used as antiviral agents due to associated properties like high surface area: volume ratio, high retention capacity, enhanced mechanical strength, high loading capacity, etc. (Donskyi et al. 2019; Lategan et al. 2018; Aliyev et al. 2019). As graphene oxide (GO) as well as reduced graphene oxide (rGO) show enhanced antimicrobial properties, they might act as promising antiviral agents as well. Antiviral activities of GO and rGO have been tested against DNA and RNA viruses and these nanoparticles have been observed to inactivate porcine epidemic diarrhoea virus (PEDV) and pseudorabies virus (PRV) in a dose-dependent and time-dependent manner where physical interactions between graphene derivatives and the virus have been reported to be responsible for its antiviral potential (Ye et al. 2015; Lee 2015). As PEDV is a coronavirus, it is estimated that GO might serve as an effective antiviral agent against SARS-CoV-2 as well. However, detailed experimental evidences are needed for the same. GO has also been reported to inactivate bacteriophage MS2 by virtue of its photocatalytic potential. GO-aptamer-based nanosheets have been used to capture MS2 bacteriophage followed by its inactivation by damaging its capsid protein thereby killing the virus (Hu et al. 2012).

Functionalized graphene derivatives have also been used as a mimic of cell membrane receptors thereby avoiding interaction of virus with the cell membrane thus preventing entry of virus into the host cell (Sametband et al. 2014). For example, polyglycerol sulfate-functionalized GO has shown to inhibit entry of PRV as well as African swine flu virus (ASFV). Both the viruses interact with polyglycerol sulfatefunctionalized GO as it mimics heparin sulfate which is naturally present in the host cell membrane and is responsible for viral entry. As the virus associates with functionalized GO, it does not interact with the host cell, thereby inhibiting viral entry (Ziem et al. 2017). GO has been used as a platform in enzyme activity assays for inhibiting viral helicase. GO has been observed to interact with the viral genome via $\pi-\pi$ stacking thereby inhibiting viral genome replication.

Table 2 Antiviral properties of carbon-based nanoparticles

\begin{tabular}{|c|c|c|c|}
\hline Nanoparticles & Virus & Mode of action & References \\
\hline $\begin{array}{l}\text { Graphene oxide, reduced graphene } \\
\text { oxide }\end{array}$ & $\begin{array}{l}\text { Porcine epidemic diarrhoea virus, } \\
\text { Pseudorabies virus }\end{array}$ & $\begin{array}{l}\text { Direct interaction with the virus } \\
\text { results in viral inactivation }\end{array}$ & Ye et al. (2015), Lee (2015) \\
\hline $\begin{array}{l}\text { Polyglycerol sulphate functionalized } \\
\text { graphene oxide }\end{array}$ & $\begin{array}{l}\text { African swine flu virus, Pseudora- } \\
\text { bies virus }\end{array}$ & $\begin{array}{l}\text { Inhibition of interaction between the } \\
\text { virs and the host cell }\end{array}$ & Ziem et al. (2017) \\
\hline Graphene oxide & $\begin{array}{l}\text { Severe acute respiratory syndrome } \\
\text { coronavirus }\end{array}$ & $\begin{array}{l}\text { Inactivation of viral helicases } \\
\text { thereby inhibiting viral replication }\end{array}$ & Jang et al. (2010) \\
\hline Boronic acid-conjugated carbon dots & Herpes simplex virus 1 & $\begin{array}{l}\text { Interference with the viral ingress in } \\
\text { the host cells }\end{array}$ & Barras et al. (2016) \\
\hline $\begin{array}{l}\text { Poly-ethylene diamine and ascorbate } \\
\text { functionalized carbon dots }\end{array}$ & $\begin{array}{l}\text { Porcine reproductive and respira- } \\
\text { tory syndrome virus, Pseudorabies } \\
\text { virus }\end{array}$ & Inhibition of viral replication & Du et al. (2016) \\
\hline Boronic acid-conjugated carbon dots & Human coronavirus $229 \mathrm{E}$ & $\begin{array}{l}\text { Interaction with the receptor spike } \\
\text { protein results in inhibition of } \\
\text { viral entry into the host cells }\end{array}$ & Łoczechin et al. (2019) \\
\hline $\begin{array}{l}\text { Protoporphyrin IX functionalized } \\
\text { multi-walled carbon nanotubes }\end{array}$ & Influenza virus & $\begin{array}{l}\text { RNA degradation, protein oxidation } \\
\text { and protein-RNA crosslinking due } \\
\text { to ROS generation }\end{array}$ & Kumar et al. (2014) \\
\hline Fullerene derivatives & Influenza A virus & $\begin{array}{l}\text { Inactivation of PA endonuclease } \\
\text { results in inhibition of viral replica- } \\
\text { tion or or inhibition of viral entry } \\
\text { into the host cells }\end{array}$ & Shoji et al. (2013) \\
\hline Fullerene derivatives & Human immunodeficiency virus & $\begin{array}{l}\text { Inhibition of Gag and Gag-Pol } \\
\text { polyproteins thereby arresting viral } \\
\text { maturation }\end{array}$ & Martinez et al. (2016) \\
\hline
\end{tabular}


This approach has been used in inactivation of hepatitis $\mathrm{C}$ virus as well as SARS-CoV (Jang et al. 2010, 2013). Thus, graphene-based nanomaterials have been reported to inactivate the virus by one or more mechanisms such as inhibition of association of the virus and the host cell, inhibition of RNA replication and inactivation of the virus through physical interactions. Antiviral therapy using graphene-based nanomaterials targeting one or more such mechanisms can be developed against SARS-CoV-2. However, there is need of relevant experimental evidences of their use in COVID-19 therapeutics for their clinical applications.

\section{Carbon dots}

Carbon dots (CDs) are carbon-based nanoparticles showing quasi-spherical morphology and size range 1-10 nm which exhibits optical properties of traditional semi-conductors as well as electrical properties of $\mathrm{sp}^{2}$-hybridized carbon atoms (Wang et al. 2017). Owing to its multi-faceted properties like tunable photoluminescence, high quantum yield, inert nature, ease of synthesis, feasibility in surface functionalization, low cytotoxicity, photocatalytic characteristics, etc. these CDs have been exploited in various fields like bio-sensing, bio-imaging, drug delivery, antimicrobial therapy, catalysis, biomedicine, etc. (Kasouni et al. 2019; Dong et al. 2017). Antiviral properties of CDs are relatively recent; however, they show excellent potential for its use in antiviral therapy with detailed study. A recent study demonstrates use of boronic acid-conjugated CDs against HSV-1 in Vero and A549 cells. Three boronic acid-conjugated CDs, i.e., phenylboronic acid functionalized CDs (PBA-CDs), 4-aminophenylboronic acid hydrochloride (4-APBACDs) functionalized CDs and 3-aminophenylboronic acid (3-APBA-CDs) functionalized CDs have been tested for biocompatibility as well as antiviral activity. All three boronic acid-conjugated CDs do not show any cytotoxicity against A549 cells. Vero cells show moderate cytotoxic response on treatment with 3-APBA-CDs in comparison with PBACDs and 4-APBA-CDs which show no cytotoxicity. Both 3-APBA-CDs and 4-APBA-CDs show excellent antiviral properties with no trace of viral infection and $100 \%$ biocompatibility whereas PBA-CDs do not show any antiviral activity. Modified boronic acid conjugated CDs inhibit viral infection by interfering with the viral ingress in the host cells thereby contributing to the antiviral properties of functionalized CDs (Barras et al. 2016). In another study, antiviral potential of PEG-diamine and ascorbate functionalized CDs against porcine reproductive and respiratory syndrome virus (PRRSV) as well as Pseudorabies Virus (PRV) has been reported as represented in Fig. 6. Monkey kidney cells (MARC-145) have been infected by PRRSV while porcine kidney cells (PK-15) have been infected by PRV. Antiviral activities of CDs on PRV and PRRSV were investigated by checking its effect upon viral replication using plaque assay. There was significant decrease in intracellular as well as extracellular viral titers after treatment with CDs as compared to untreated cells highlighted antiviral properties of CDs when tested in triplicates with a $p$ value $<0.05$ against both the viruses. Furthermore, effect of CDs on the expression profiles of type 1 interferon $\alpha($ IFN- $\alpha$ ) and interferon stimulating genes (ISGs) with downstream action were analyzed to understand the plausible mechanism for antiviral
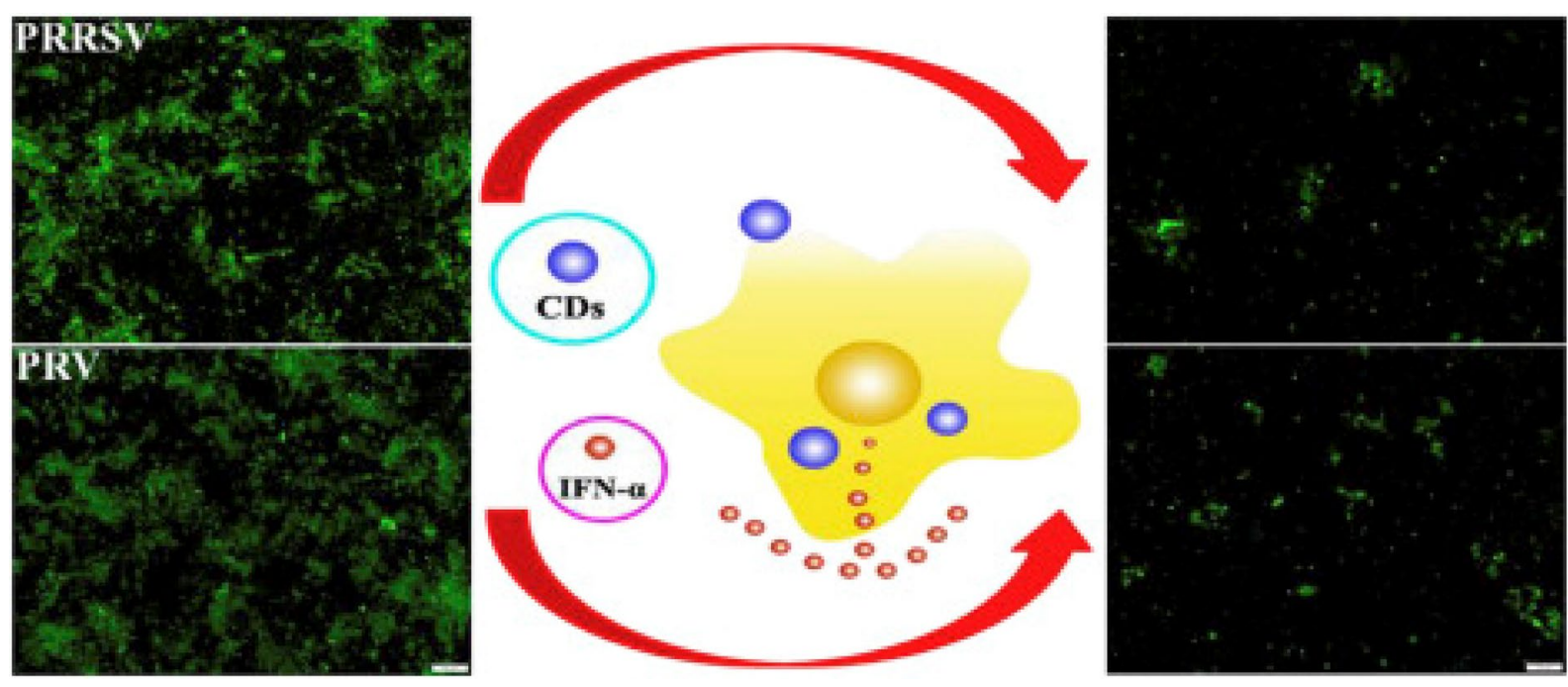

Fig. 6 Antiviral activity of poly-ethylene glycol diamine and ascorbate functionalized carbon dots (CDs) against porcine reproductive and respiratory syndrome virus (PRRSV) and pseudorabies Virus (PRV) by inhibition of viral replication Reproduced with permission from Du et al. (2016) Carbon dots as inhibitors of virus by activation of type I interferon response. Carbon 110:278-285. Copyright @ Elsevier 
potential of CDs. There was a fivefold increase in IFN- $\alpha$ expression levels in treated cells as compared to the control group along with significant upregulation of several ISGs like interferon inducible protein 10 (IP-10), interferon stimulated gene 15 (ISG-15) and interferon stimulated gene 54 (ISG-54) showing 24.8-fold 11.8-fold and 4.6-fold increase in treated cells as compared to untreated cells. Thus, antiviral potential of CDs was a cumulative effect of IFN- $\alpha$ activation along with upregulation of ISGs thereby inhibiting viral replication (Du et al. 2016).

CDs have also been observed to show antiviral potential against coronavirus making it a promising candidate to be exploited for antiviral therapy thereby controlling the current COVID-19 pandemic crisis which the world has been facing. Curcumin-mediated synthesis of cationic carbon dots (CCM-CDs) have shown antiviral properties against porcine epidemic diarrhea virus (PEDV) used as model system for studying coronavirus as shown in Fig. 7. Antiviral activity of the CCM-CDs was studied with the help of one-step growth curve assay by evaluating the infectivity levels of PEDV. Vero cells were treated with PEDV which were further exposed to CCM-CDs at a concentration of $125 \mu \mathrm{g} / \mathrm{mL}$ after which viral replication was quantified by measuring viral titers in treated and control groups. Decrease in viral titers was observed in treated cells in comparison
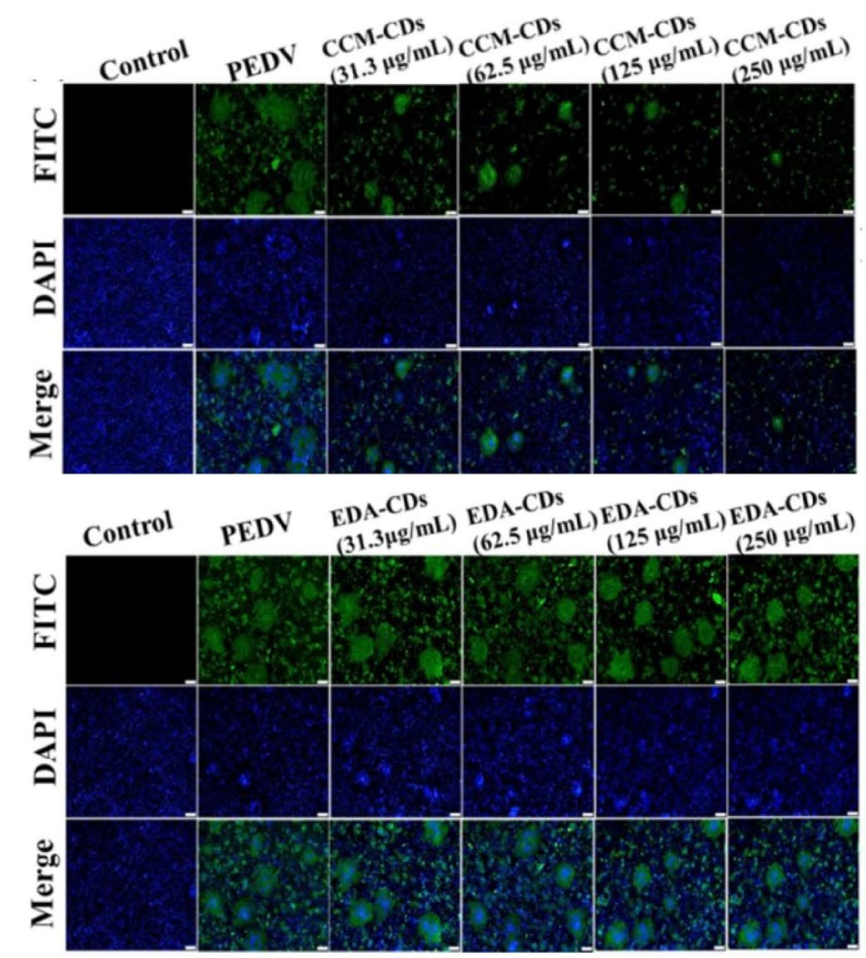

Fig. 7 Comparative analysis of antiviral activities of curcumin coated cationic carbon dots (CCM-CDs) and ethylenediamine functionalized carbon dots (EDA-CDs) against porcine epidemic diarrhea virus (PEDV) in a dose-dependent manner Reproduced with permission with untreated cells showing antiviral properties of CCMCDs on PEDV. Similarly, antiviral potential of ethylenediamine functionalized CDs (EDA-CDs) on PEDV was also evaluated. EDA-CDs could not inhibit viral infection even at higher concentrations. Comparative analysis of antiviral potential showed decreased viral titer and plaque formation in CCM-CDs as compared to EDA-CDs. Thus, CCM-CDs have been observed to inhibit viral replication with higher efficiency as compared to EDA-CDs in a dose-dependent manner. The cationic nature of CCM-CDs helps in stronger associations of the CDs with viral particles as well as host cell membrane thereby inhibiting attachment of PEDV to the host cell through competitive inhibition. Moreover, CCMCDs also cause irreversible alterations of viral proteins along with inhibition of viral genome replication by suppressing RNA strands due to oxidative stress and production of interferon-stimulated genes (ISGs) and cytokines which ultimately leads to inactivation of the virus (Ting et al. 2018). In another study, antiviral potential of seven different surface functionalized CDs were tested using human coronavirus HCoV-229E. Boronic acid-conjugated CDs synthesized using ethylenediamine/citric acid was observed to inhibit $\mathrm{HCoV}-229 \mathrm{E}$ in a dose-dependent manner. CDs synthesized using 4-aminophenylboronic acid showed higher antiviral activity with effective $\mathrm{HCoV}-229 \mathrm{E}$ inhibition. Both these

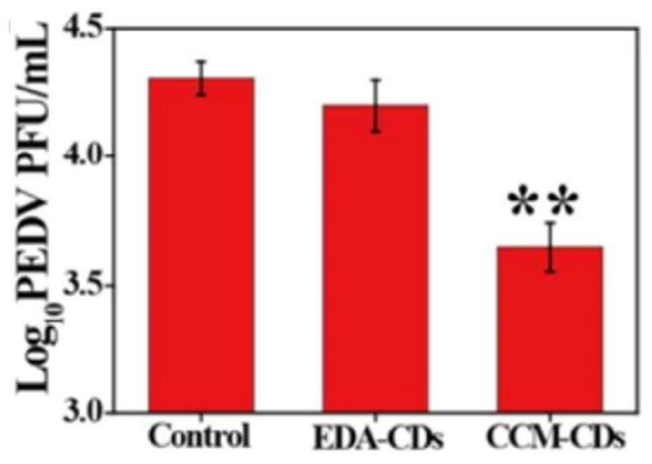

\section{Control EDA-CDs CCM-CDs}



from Ting et al. (2018) Multisite inhibitors for enteric coronavirus: antiviral cationic carbon dots based on curcumin. ACS Appl Nano Mater 1:5451-5459. Copyright @ American Chemical Society 
CDs associate with the receptor spike protein inhibits interaction of the viral particles with host cell receptors thereby inhibiting their entry into the host cells ultimately leading to viral inactivation. In addition to this, these CDs were also observed to cause viral inactivation by interfering with the viral genome replication (Łoczechin et al. 2019). As functionalized CDs are known to inhibit coronavirus in general, these nanoparticles can prove to be a promising antiviral agent to be used in COVID-19 therapeutics. However, experimental evidences regarding its mechanism of action against SARS-CoV-2 are mandatory for its use in clinical applications.

\section{Carbon nanotubes}

Carbon nanotubes (CNTs) have been reported to be cylindrical-shaped graphene sheet-like structures which consist of carbon atoms with $\mathrm{sp}^{2}$ hybridization. CNTs are categorized into single-walled CNTs (SWCNTs), double-walled CNTs (DWCNTs) as well as multi-walled CNTs (MWCNTs) considering the amount of graphene tubes in CNTs (Ibrahim 2013). CNTs are widely exploited for different applications involving polymers, catalysis, opto-electronics, bio-sensors, energy conversion, nanocomposites, bio-medicine, etc. (Bekyarova et al. 2006). CNTs have been extensively used in antimicrobial therapy, drug delivery, disease therapy, regenerative medicine, bio-sensing, etc. (Alshehri et al. 2016). The associated side-effects arising from use of CNTs for biomedical applications include inherent cytotoxicity due to ROS generation and inflammation as well as high hydrophobic nature which highly limit its use in in vivo applications. These shortcomings have been overcome by surface functionalization using natural polymers as well as bio-macromolecules contributing to its hydrophilicity as well as biocompatibility. Functionalized CNTs are then used for therapeutic applications (Eatemadi et al. 2014). MWCNTs functionalized using protoporphyrin IX (PPIX) have demonstrated to be used for treating influenza virus by photodynamic therapy. PPIX-functionalized MWCNTs have been observed to cause RNA degradation, protein oxidation as well as crosslinking of proteins with RNA because of ROS generation thereby causing inactivation of the influenza virus. PPIX-functionalized MWCNTs have also shown similar action on multiple viruses making them a promising alternative to be used in antiviral therapy (Kumar et al. 2014). In another study, computational chemistry-based approach was undertaken to study interactions of CNTs with key structural proteins of HIV. Armchair, chiral and zigzag CNTs were estimated for molecular interactions with Vpr, Nef and Gag proteins of HIV through molecular docking studies. It was observed that CNTs showed high affinity binding with these structural proteins which makes CNTs a promising candidate to be explored for retroviral therapy
(Krishnaraj et al. 2014). As CNTs have been reported to show antiviral potential against HIV which is a retrovirus, there is a possibility that it might also prove to be effective against SARS-CoV-2. However, detailed understanding is necessary for its use in COVID-19 therapeutics.

Additionally, functionalized CNTs have been reported to show biocompatible nature in respiratory system underlining that if these nanoparticles are used in antiviral therapy of SARS-CoV-2, it will only damage the virus and not the host cells. Biocompatibility of CNTs functionalized using hyaluronic acid was observed in bronchial cells. These hyaluronic acid-functionalized CNTs further prevented onset of inflammation in pulmonary tissues thereby underlining its effective use against viral infections affecting the respiratory system (Hussain et al. 2016). Increased specificity for lung cell receptors has been observed upon action of SWCNTs conjugated with anti-CTLA-4 antibodies thereby ensuring targeted drug delivery (Wang et al. 2014). CNTs have also been used as nano-carriers for loading retroviral drugs which were efficient in inhibiting reverse transcriptase enzyme in HIV-infected patients thereby underlining its potential use in retroviral therapy (Iannazzo et al. 2015). Thus, given the improved efficacy, controlled drug release, increased specificity as well as biocompatibility towards respiratory system, CNTs can prove to be a promising antiviral agent in treating SARS-CoV-2. However, there is need to study the antiviral potential of CNTs in COVID-19 therapeutics in depth for its clinical applications.

\section{Fullerenes}

Fullerene molecules are the most commonly occurring allotrope of carbon which is entirely made up of carbon atoms constituting structures like sphere, tube or ellipse. These C60 molecules are highly symmetrical conjugated with double bonds. Fullerene structures consist of 20 hexagons along with 12 pentagons which are fused with each other (Taylor et al. 1990). The unique physical and chemical properties such as high conductivity, enhanced surface area, inert nature, biocompatibility as well as easy functionalization attributed to these fullerene molecules have resulted in exploitation of these molecules for various biomedical applications such as drug delivery, gene delivery, cancer therapy, disease treatment, bio-imaging, antiviral therapy, bio-sensing, etc. Fullerene molecules have been used in antimicrobial and antiviral therapy as well as drug delivery applications by virtue of its unique physico-chemical properties, ease of surface functionalization, reduction in oxidative stress as well as high biocompatibility (Partha and Conyers 2009; Bakry et al. 2007). However, low solubility and high cytotoxicity of fullerene molecules has always been an issue with its use in in vivo applications. Surface functionalization has aided in enhancing the hydrophilic nature and decreasing 
cytotoxicity of fullerene molecules rendering it useful in various biomedical applications (Nakamura and Isobe 2003; Troshina et al. 2007). Antiviral potential of several fullerene derivatives have been analyzed against influenza viruses. A series of 12 different fullerene derivatives were checked for its antiviral properties via estimating its influence on in vitro PA endonuclease activity as PA is a subunit of influenza A RNA polymerase. Out of the 12 fullerene derivatives, 8 have been observed to show antiviral activities against influenza virus by PA endonuclease inhibition. This antiviral activity is by virtue of RNA cleavage which arrests viral genome replication or inhibition of viral entry into the host cells. Thus, fullerene derivatives show excellent potential to be developed into anti-influenza drugs (Shoji et al. 2013).

Additionally, fullerene derivatives have been reported to be used in antiviral therapy. There are many reports regarding its use in antiretroviral therapy against HIV by inhibiting different enzymes critical in life cycle of HIV (Innocenzi and Stagi 2020). For example, fullerene molecules bind to HIV proteases into the hydrophobic cavity by virtue of its hydrophobic nature and inhibit viral replication of HIV via competitive inhibition (Friedman et al. 1993). In another study, different fullerene derivatives have been observed to inhibit Gag and Gag-Pol derived polyproteins which are crucial for maturation of HIV-1. These fullerene derivatives have been found to inhibit processing of Gag independent of protease action thereby arresting viral maturation. The viral particles so formed released from the host cell are immature and lack virulence. The use of fullerene derivatives can also be done in antiretroviral therapy against HIV strains resistant to protease inhibition (Martinez et al. 2016). As HIV and SARS-CoV-2 both are retroviruses, approaches involved in inactivation of HIV by fullerene derivatives can be further extrapolated in COVID-19 therapeutics, provided detailed analysis is performed to study the action of fullerene derivatives on SARS-CoV-2.

\section{Quantum dots}

Quantum dots (QDs) are semiconductor-based nanoparticles which include elements from group II to group VI with diameter within the range of 1-10 nm with unique properties in comparison with larger nanoparticles (Chan et al. 2002). QDs have been observed to display distinctive photoluminescence as well as electronic characteristics which include broad and uninterrupted absorption spectra, restricted emission spectra as well as enhanced photo-stability (Bruchez et al. 1998). Due to its multi-faceted natures, QDs have been widely used in various bio-applications like intracellular tracking of biomolecules, cellular tracking at tissue level, bio-labeling organelles and cells, bio-imaging, clinical applications, etc. (Valizadeh et al. 2012). Some frequently used quantum dots include cadmium telluride (CdTe), cadmium selenide (CdSe), zinc selenide ( $\mathrm{ZnSe}$ ), zinc sulphide ( $\mathrm{ZnS}$ ), carbon, silver, gold, etc. (Michalet et al. 2005). However, there are very few studies reporting antiviral properties of QDs as mentioned in Table 3 (Manivannan and Ponnuchamy, 2020).

There are reports displaying interaction of positive charged QDs with negative RNA viral strand thereby causing increased ROS generation ultimately resulting in viral inactivation which can be extrapolated for inactivation of SARS-CoV-2 (Dong et al. 2017; Chen and Liang 2020). Carbon dots functionalized with 4-aminophenyl boronic acid hydrochloride (4-AB/C-dots) have been observed to show antiviral properties against herpes simplex virus type 1 by inhibiting the viral infection at an early stage (Barras et al. 2016). Similarly, antiviral potential of carbon dots against pseudorabies virus as well as porcine reproductive and respiratory syndrome virus have also been reported (Du et al. 2016). Carbon quantum dots (CQDs) synthesized by hydrothermal carbonization of ethylenediamine/citric acid have been observed to inhibit the viral entry and replication by

Table 3 Antiviral properties of quantum dots

\begin{tabular}{|c|c|c|c|}
\hline Nanoparticles & Virus & Mode of action & References \\
\hline $\begin{array}{l}\text { 4-aminophenyl boronic acid hydrochlo- } \\
\text { ride functionalized carbon dots }\end{array}$ & Herpes simplex virus 1 & $\begin{array}{l}\text { Inhibition of viral infection at an early } \\
\text { stage }\end{array}$ & Barras et al. (2016) \\
\hline $\begin{array}{l}\text { Poly-ethylene glycol diamine and ascor- } \\
\text { bate functionalized carbon dots }\end{array}$ & $\begin{array}{l}\text { Porcine reproductive and respira- } \\
\text { tory syndrome virus, Pseudorabies } \\
\text { virus }\end{array}$ & Inhibition of viral replication & Du et al. (2016) \\
\hline Carbon quantum dots & Human coronavirus $229 \mathrm{E}$ & $\begin{array}{l}\text { Inhibition the viral entry and replica- } \\
\text { tion by interfering with the viral } \\
\text { binding with the host cell receptors } \\
\text { functioning in viral entry }\end{array}$ & Łoczechin et al. (2019) \\
\hline $\begin{array}{l}\text { Curcumin-functionalized cationic } \\
\text { carbon dots }\end{array}$ & Porcine epidemic diarrhea virus & $\begin{array}{l}\text { Structural modification of the viral sur- } \\
\text { face protein followed by suppression } \\
\text { of viral replication, viral budding and } \\
\text { ultimately inhibition viral entry into } \\
\text { the host cell by ROS generation }\end{array}$ & Du et al. (2018) \\
\hline
\end{tabular}


interfering with the binding of $\mathrm{HCoV}-229 \mathrm{E}$ with the host cell receptors functioning in viral entry (Łoczechin et al. 2019). Furthermore, functionalization of carbon dots with biomolecules result in increased biocompatibility as well as stability because of which it is a much preferred alternative. This has been confirmed in case of curcumin-functionalized cationic carbon dots (CCM-CDots) which showed much higher antiviral potential by inhibiting viral proliferation when tested against porcine epidemic diarrhea virus (PEDV) which acts as a coronavirus model as compared to non-CCM-CDots. The mechanism for viral inactivation by CCM-CDots include structural modification of the viral surface protein followed by suppression of viral replication, viral budding and ultimately inhibition viral entry into the host cell by ROS generation (Du et al. 2018).

Even though enhanced antiviral properties have been observed using quantum dots with different surface functionalization, the exact mechanism with which these nanoparticles act is not yet completely understood. Also, quantum dots have been observed to show high cytotoxicity in in vivo studies which majorly limits their use. Thus, detailed analysis needs to be done by designing approaches for synthesizing QDs followed by functionalization with novel molecules which would act against SARS-CoV-2 thereby inactivating it and facilitating the control of COVID-19 infection.

\section{Polymeric nanoparticles}

Polymeric nanoparticles have been extensively utilized for different biomedical applications as a result of their attributed properties such as easy design, biocompatible nature, high stability, specificity, bioavailability, efficacy and other bio-imitative properties (El-Say and El-Sawy 2017). Polymeric nanoparticles can be synthesized using natural, synthetic as well as semi-synthetic polymers. Some polymers like polylactic acid (PLA), polyethylene glycol (PEG), polyglycolic acid (PGA), polystyrene, polylactic-co-glycolic acid (PLGA), polymethacrylate (PMMA), chitosan, cellulose, gelatin, starch, etc., have been extensively used especially in drug delivery applications due to their biocompatibility and biodegradability (Torchilin 2009; Calzoni et al. 2019). Polymeric nanoparticles can be used in antiviral therapy as multi-faceted properties of these nanoparticles can be easily modulated so as to ensure targeted delivery of loaded drugs to specific target locations as represented in Table 4. These nanoparticles can be used as nano-carriers to deliver antiviral agents into the host cells which then interfere with the life cycle of the infected virus thereby resulting in its inactivation (Chakravarty and Vora 2020). For example, $\beta$-cyclodextrin-poly(4-acryloylmorpholine) mono-conjugate $(\beta$-CD-PACM)-based polymeric nanoparticles have shown excellent intracellular uptake ensuring effective delivery to target location inside the cell. $\beta$-CD-PACM nanoparticles loaded with antiviral drugs like acyclovir has shown remarkable antiviral activity against HSV-1 in comparison free drugs as well as $\beta$-CD-PACM nano-carriers by inhibiting viral entry/attachment to the host cells (Cavalli et al. 2009). In another study, PEG-PLGA diblock copolymer-based nanoparticles loaded with V-ATPase inhibitors diphyllin and bafilomycin have been observed to increase antiviral efficiency against two influenza virus subtypes (H1N1 and H3N2) along with decreased cytotoxicity in lung cells. The higher antiviral property of polymeric nanoparticles loaded with V-ATPase inhibitors as compared to free drugs makes them suitable to be used as anti-influenza drugs (Hu et al. 2018).

Different polymeric nanoparticles have been used as nano-carriers for targeted release of silencing RNA

Table 4 Antiviral properties of polymeric nanoparticles

\begin{tabular}{|c|c|c|c|}
\hline Nanoparticles & Virus & Mode of action & References \\
\hline $\begin{array}{l}\beta \text {-cyclodextrin-poly(4- } \\
\text { acryloylmorpholine) mono-conjugate } \\
\text { based polymeric nanoparticles }\end{array}$ & Herpes simplex virus 1 & $\begin{array}{l}\text { inhibiting viral entry/attachment into } \\
\text { the host cells }\end{array}$ & Cavalli et al. (2009) \\
\hline $\begin{array}{l}\text { Poly(lactic-co-glycolic acid) polymeric } \\
\text { nanoparticles loaded with siRNA } \\
\text { against UL28 }\end{array}$ & Herpes simplex virus 2 & $\begin{array}{l}\text { Inactivation of HSV protein crucial for } \\
\text { viral genome replication }\end{array}$ & Steinbach et al. (2012) \\
\hline $\begin{array}{l}\text { Hydrophilic } N \text {-(2-hydroxypropyl)- } \\
\text { 3-trimethylammonium chitosan } \\
\text { chloride (HTCC), hydrophobically } \\
\text { modified HTCC (HM-HTCC) }\end{array}$ & Human coronavirus NL63 & $\begin{array}{l}\text { Inhibition of viral replication through } \\
\text { direct interactions }\end{array}$ & Milewska et al. (2013) \\
\hline $\begin{array}{l}\text { Diphyllin functionalized poly(ethylene } \\
\text { glycol)-block-poly(lactide-co-gly- } \\
\text { colide) polymeric nanoparticles }\end{array}$ & $\begin{array}{l}\text { Feline infectious peritonitis virus } \\
\text { type II }\end{array}$ & $\begin{array}{l}\text { Inhibition of the downstream virus } \\
\text { replication }\end{array}$ & Hu et al. (2017) \\
\hline $\begin{array}{l}\text { Mercaptoethane sulfonate functional- } \\
\text { ized bovine serum albumin-coated } \\
\text { tellurium nanoparticles }\end{array}$ & $\begin{array}{l}\text { Porcine reproductive and respiratory } \\
\text { syndrome virus, Porcine epidemic } \\
\text { diarrhea virus }\end{array}$ & $\begin{array}{l}\text { Repression of adsorption, internaliza- } \\
\text { tion and replication stages of viral } \\
\text { infection }\end{array}$ & Zhou et al. (2020a) \\
\hline
\end{tabular}


(siRNA) molecules for viral inhibition. siRNA molecules have been observed to silence mRNA molecules by binding to complementary mRNA strands resulting in inhibition of protein synthesis of viral proteins important in life cycle of the virus thereby causing viral inactivation. Antiviral therapies have been adapted against several viral families by designing siRNA molecules targeting mRNA sequences conserved throughout the viral family thereby resulting in broad spectrum viral inhibition (Reynolds et al. 2017). For example, poly(lactic-co-glycolic acid) (PLGA) polymeric nanoparticles loaded with siRNA against UL28 which is a HSV protein crucial for viral genome replications as well as nectin1 which is HSV receptor on the host cell have been observed to prolong survival of host cells by knocking down HSV-2 infection. The increased host cell survival has been observed from 9 days in untreated mice to 28 days in PLGA-siRNA treated mice thus proving its antiviral potential against HSV-2 (Steinbach et al. 2012). In another study, polyethyleneimine (PEI) nanoparticles have been used as nano-carriers to load siRNA against conserved sequences in influenza virus. PEI-based siRNA delivery system was used for preferential delivery of siRNA molecules to the lungs as well as inhibition of the influenza virus by interfering with the viral replication causing more than 1000-fold reduction in the viral titer. However, PEI-based nano-carriers cause acute inflammatory response in the lung cells which can be overcome by conjugating them with PEG. PEG-PEI-based nano-carriers show reduced pro-inflammatory response with minimal ROS generation in lungs which is favorable for its use in siRNA delivery (Ge et al. 2004; Beyerle et al. 2011). As far as use of polymeric nanoparticles for targeting lung infections is concerned, surface modification with PEG has been observed to be a promising strategy as it ensures even distribution and high circulation times in the lung tissue, thus increasing the efficacy of antiviral therapy (Shen et al. 2015).

Polymeric nanoparticles have been reported to be used in antiviral therapy against coronavirus. Two chitosan derivatives, viz., hydrophilic $N$-(2-hydroxypropyl)-3-trimethylammonium chitosan chloride (HTCC) as well as hydrophobically modified HTCC (HM-HTCC) were evaluated for biocompatibility using LLC-MK2 and LR7 cell lines as well as antiviral activities against human coronavirus $\mathrm{HCoV}$ NL63 as represented in Fig. 8. Both the polymers were evaluated for their antiviral potential on cytopathic effect which include morphological alterations and cell attachment
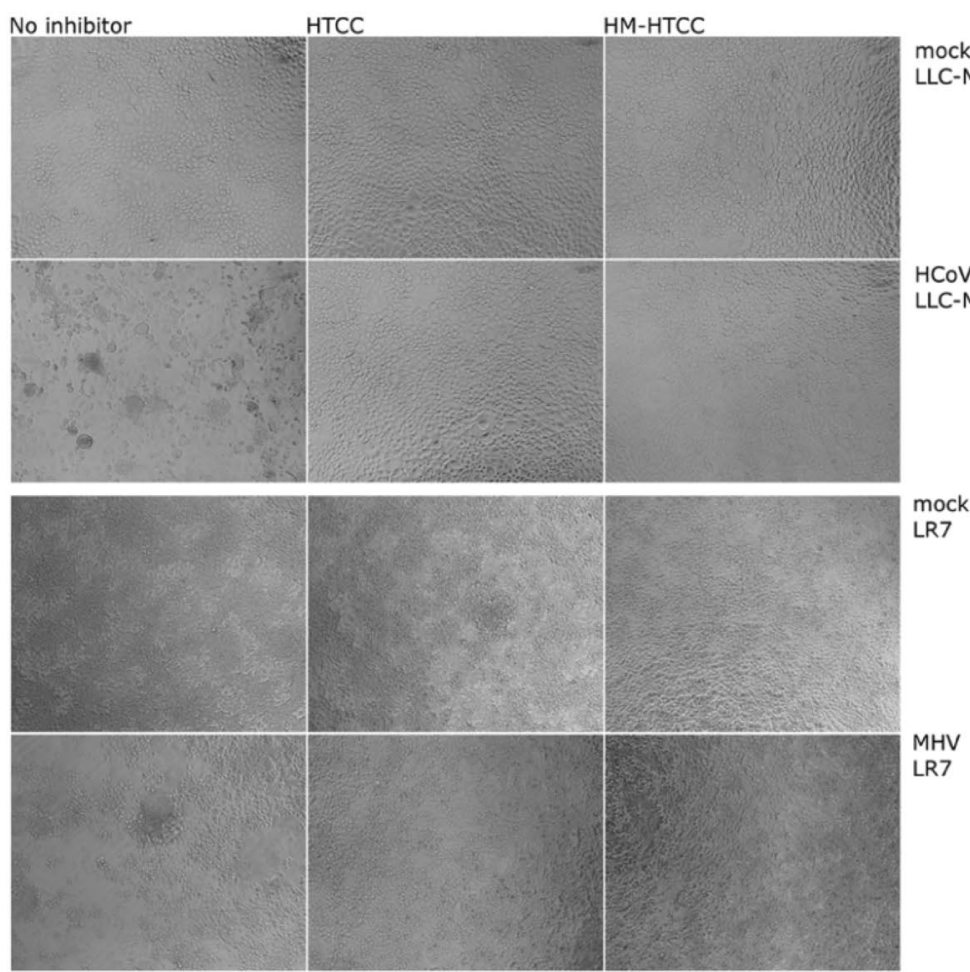
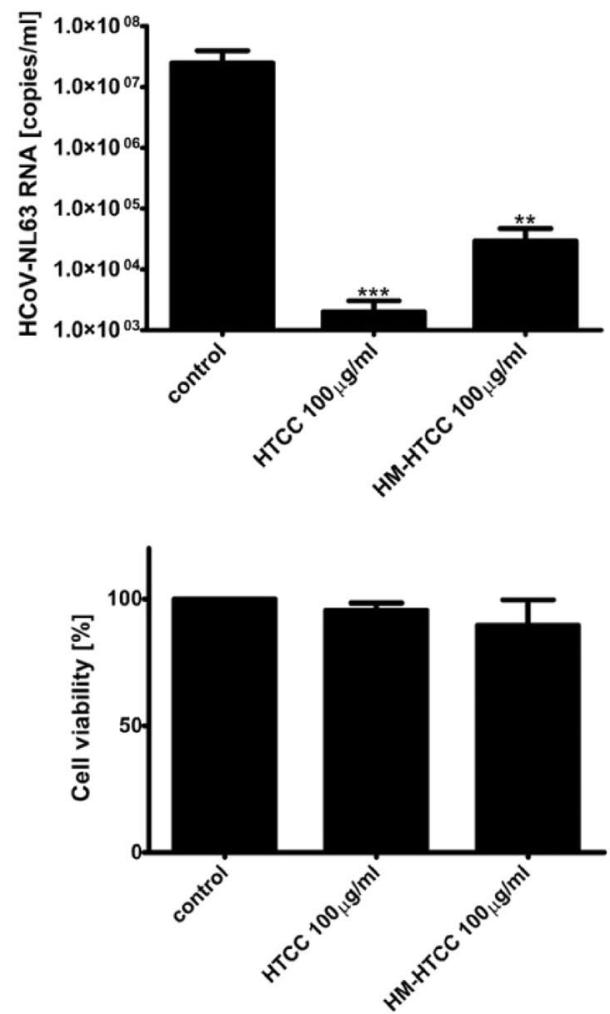

Fig. 8 Antiviral activities of hydrophilic $N$-(2-hydroxypropyl)-3-trimethylammonium chitosan chloride (HTCC) as well as hydrophobically-modified HTCC (HM-HTCC) HTCC and HM-HTCC against human coronavirus NL63 (HCoV-NL63) and murine hepatitis virus (MHV) using LLC-MK2 and LR7 cells and its cell viability stud- ies using human airway epithelium (HAE) cell cultures Reproduced with permission from Milewska et al. (2013) Novel polymeric inhibitors of HCoV-NL63. Antiviral Res 97:112-121. Copyright @ Elsevier 
after infection with human coronavirus NL63 (HCoV-NL63) and murine hepatitis virus (MHV). CPE is evident usually 4-6 days after infection which is a direct measure of production of viral particles. Both HTCC and HM-HTCC were observed to prevent morphological alterations as well as host cell death following viral infection. However, reduced CPE may be due to intrinsic cellular mechanisms of the host cell and not actual inhibition of viral entry or replication. To confirm this, viral titers were evaluated using quantitative RTPCR - based assay under treatment with HTCC and HMHTCC. It was observed that there is remarkable reduction in viral titre after treatment with the both polymers. However, there was significant difference in $\mathrm{IC}_{50}$ values with $\mathrm{HTCC}$ and HM-HTCC showing $\mathrm{IC}_{50}$ values of $2.75 \pm 1.18 \mu \mathrm{g} /$ $\mathrm{ml}(13.41 \mathrm{nM})$ and $68.52 \pm 18.71 \mu \mathrm{g} / \mathrm{ml}(308.65 \mathrm{nM})$, respectively, thus highlighting higher antiviral activities of HM-HTCC as compared to HTCC. Furthermore, antiviral potential of both the polymers were tested on human airway epithelium (HAE) cell cultures to assess their activity in a more natural environment as HAE culture imitates natural conductive airway epithelium. Viral titers were evaluated in HCoV-NL63 infected HAE cultures after treatment with both the polymers using quantitative RT-PCR-based assay. Significant reduction in viral titres was observed posttreatment with both the polymers. Also, these polymers did not show any cytotoxicity against HAE cultures. Thus, both HTCC and HM-HTCC showed high biocompatibility when tested using HAE cultures. Significant antiviral activities were observed in both polymers when tested against $\mathrm{HCoV}$ NL63. As size and surface charge of polymers do not influence its antiviral potential, HTCC polymers inhibit viral replication through direct interactions. These polymers can thus be used as anticoronviral drugs (Milewska et al. 2013). It is known that association of spike protein of SARS-CoV-2 and the ACE2 receptors of the host cells is critical in attachment/ entry of viral particles into the host cell (Yang and Shen 2020). Inhibition of this interaction might also severe as a strategy to avoid SARS-CoV-2 infection. Antagonistic effect of non-peptide angiotensin receptors blockers conjugated with branched PEG and poly(amido amine) (PAMAM) on angiotensin receptors can be useful in preventing association of SARS-CoV-2 with the ACE2 receptors ultimately inhibiting viral entry by blocking the ACE2 receptors. This inhibition of association of SARS-CoV-2 spike protein with the ACE2 receptors ultimately leads to viral inactivation due to lack of entry/attachment of viral particles into the host cells (Figueroa et al. 2019; Hennig et al. 2015). In the light of current COVID-19 pandemic situation, the strategies undertaken for inactivation of other viruses belonging to the coronavirus family may pose to be effective in inhibiting the novel SARS-CoV-2 as well.

\section{Lipid-based nanoparticles}

Lipid-based nanoparticles are yet another class of nanoparticles which have been exploited in various biomedical applications. These nanoparticles have been frequently used in targeted delivery of antiviral agents due to their unique properties like high biocompatibility, highly biodegradable nature, inertness, negligible cytotoxicity, minimal immunogenicity, easy availability, low cost, etc. as elaborated in Table 5 (García-Pinel et al. 2019). Lipid-based nanoparticles have been preferred over other classes of nanoparticles due to their biocompatible nature as lipids constitute one of the major components of every living cell and hence there is no associated immune response even after repeated use (Kulkarni 2012). Various types of lipid-based nanoparticles such as micelles, solid lipid nanoparticles, liposomes, nanostructured lipid carriers, lipid nanocapsules, drug-lipid composites, etc., have been used as successful drug delivery systems after loading them with therapeutic drugs, vaccines or any other material of choice which needs to be delivered in living systems (Moghimi et al. 2005; Battaglia and Ugazio 2019). Use of lipid-based nanoparticles as nano-carriers has been already established in antiviral therapy of HIV, HSV,

Table 5 Antiviral properties of lipid-based nanoparticles

\begin{tabular}{llll}
\hline Nanoparticles & Virus & Mode of action & References \\
\hline Ivermectin loaded liposomes & Dengue virus & $\begin{array}{c}\text { Interference with viral genome replica- } \\
\text { tion }\end{array}$ & Croci et al. (2016) \\
$\begin{array}{c}\text { Positively charged liposomes contain- } \\
\text { ing } N \text {-[1-(2,3-Dioleoyloxy)propyl]- } \\
\begin{array}{l}N, N, N \text {-trimethylammonium, nega- } \\
\text { tively charged liposomes containing } \\
\text { phosphatidylserine, neutral phos- } \\
\text { phatidylcholine containing liposomes }\end{array}\end{array}$ & $\begin{array}{l}\text { Equine herpes virus type 1 } \\
\text { particles and the liposomes thereby } \\
\text { avoiding viral attachment to the host } \\
\text { cells thereby inhibiting viral entry }\end{array}$ & Kolyvushko et al. (2020) \\
$\begin{array}{l}\text { Stearylamine embedded cationic } \\
\text { liposomes }\end{array}$ & Herpes simplex virus 1 & $\begin{array}{c}\text { Hinderance of viral attachment to the } \\
\text { host cells }\end{array}$ & Tahara et al. (2018) \\
$\begin{array}{l}\text { Solid lipid nanoparticles loaded with } \\
\text { atazanavir }\end{array}$ & Human immunodeficiency virus & $\begin{array}{c}\text { Inactivation of viral protease leading to } \\
\text { inhibition of viral replication }\end{array}$ & Chattopadhyay et al. (2008) \\
\hline
\end{tabular}


hepatitis B virus, hepatitis C virus, etc., for targeted delivery (Jain et al. 2011; Pollock et al. 2010).

Liposomes are nano-assemblies consisting of one or more lipid bilayers composed of amphipathic lipid molecules which can encapsulate hydrophilic as well as hydrophobic molecules. Liposomes have lower retention times but show high loading capacities and hence have been used as nano-carriers for targeted delivery of antiviral agents as well as vaccines (Zolnik et al. 2010). Liposome mediated delivery of ivermectin generally used to treat RNA viruses such as dengue virus, Yellow fever virus, West Nile virus, etc., showed higher solubility and low cytotoxicity in comparison with free ivermectin which show low solubility and higher cytotoxicity. Ivermectin-loaded liposomes have been observed to hamper viral genome replication thereby inactivating dengue virus (Croci et al. 2016). The constituents of the liposomes have also been observed to affect its antiviral potential. Comparative analysis of efficiency of viral inhibition of charged and uncharged liposomes showed that positively charged liposomes containing $N$-[1-(2,3-Dioleoyloxy)propyl]- $N, N, N$-trimethylammonium (DOTAP), negatively charged liposomes containing phosphatidylserine (PS) and liposomes containing neutral phosphatidylcholine (PC) against equine herpesvirus type $1(\mathrm{EHV}-1)$ has been reported. Charged DOTAP and PS facilitate membrane fusion of the viral particles and the liposomes thereby avoiding attachment of EHV-1 to the host cells resulting in inhibition of viral entry. On the contrary, neutral liposomes containing PC show no effect on viral inhibition (Kolyvushko et al. 2020). Surface modifications of liposomes further impart specificity in addition to enhancing efficient delivery to the target location. Various ligands like hydrophilic polymers, biomacromolecules, antibodies, etc. have been used to functionalize liposomes. Stearylamine (SA) embedded cationic liposomes have been observed to show excellent antiviral activities against recombinant baculovirus (BV) even without the presence of any antiviral drug. These SA-conjugated liposomes have shown comparable antiviral activities to that of the antiviral drug acyclovir against HSV-1 by hindering viral attachment to the host cells along with low cytotoxicity against A549 cells (Tahara et al. 2018). Surface functionalization of liposomes using polyethylene glycol (PEG) as well as hyperbranched polyglycerol (hbPG) has resulted in significant reduction in total proteins adsorption. PEG functionalization decreased non-specific cellular uptake whereas hbPG functionalization enhanced interaction with macrophages (Weber et al. 2019). Though there are no direct studies on use of liposomes against coronavirus, strategies involving its antiviral potential against retroviruses and specific cellular uptake can be extrapolated for COVID19 therapeutics.

As compared to liposomes, solid lipid nanoparticles (SLNs) have been considered to be a promising alternative in various biomedical applications due to its easy synthesis, controlled drug release, increased circulation times, biocompatible nature, biodegradability as well as minimal cytotoxicity. SLNs are colloidal nanoparticles within size range $50-400 \mathrm{~nm}$ consisting of surfactant-stabilized lipid molecules which can be further loaded with hydrophilic/hydrophobic therapeutic drugs to be used in antiviral therapy (Puri et al. 2009; Almeida and Souto 2007). SLNs have been extensively used for targeted delivery of various antiviral drugs like acyclovir, ritonavir, efavirenz, penciclovir, etc. (da Silva Meira et al. 2020; Alex et al. 2011; Negi et al. 2013; El-Gizawy et al. 2019). SLNs loaded with adefovir dipivoxil (ADV) have been reported to be used in antiviral therapy against hepatitis B virus (HBV). ADV is a nucleotide analogue used to reduce serum HBV DNA levels thereby fighting the infection. SLNs loaded with ADV have been observed to show significant reduction in $\mathrm{HBsAg}$, $\mathrm{HBeAg}$ as well as HBV DNA level in concentration as well as time-dependent manner (Xing-Guo et al. 2008). SLNs loaded with atazanavir which is commonly used protease inhibitor against HIV has shown higher bioavailability in endothelial cell monolayer as compared to free atazanavir thus proving efficient passage through blood brain barrier (BBB) which can be used against HIV encephalitis. Due to its prominent antiviral potential as well as ability to cross BBB, atazanavir-loaded SLNs form a potent antiviral agent to be used in antiretroviral therapy against HIV (Chattopadhyay et al. 2008). SLNs loaded with rifampicin have been observed to show biocompatible nature when tested against alveolar macrophages (AMs) as well as alveolar epithelial type II cells (AECs). These rifampicin-loaded SLNs further showed highly preferential uptake in AMs as compared to AECs which is crucial for successful treatment of pulmonary infections (Chuan et al. 2013). There is no direct evidence of use of SLNs as nano-carriers for controlled release of antiviral agents against coronavirus, but its excellent efficacy in antiretroviral therapy, low cytotoxicity against host cells as well as preferential uptake by AMs makes it a suitable candidate to be explored for COVID-19 therapeutics.

\section{Conclusions and future challenges}

Infectious diseases which are caused by various bacteria, fungi, viruses, protozoans, parasites, etc., majorly contribute to hundreds of deaths world-wide thereby posing a threat to human health as well as global economy. Viral diseases have contributed to a large number of mortalities worldwide of which respiratory infections caused by coronaviruses contributes a major portion. The world is currently facing a pandemic situation due to outbreak of one such respiratory viral infection, the COVID-19 disease. COVID-19 disease outbreak has been declared to be a pandemic according to




the World Health Organization (WHO) in March 2020 with incidence of 55,510,763 confirmed cases and 1,335,191 deaths worldwide as on 17th November 2020. Moreover, the alarming rate of infection spread in the second wave has further increased severity of this pandemic as a result of its catastrophic impact on health and economy. Due to limited understanding about SARS-CoV-2 which is responsible for the current COVID-19 disease, there is lack of therapeutic drugs or vaccines specifically targeting the virus. There is need to have a detailed understanding about physiology, epidemiology and mechanism of action of the virus as well as response of immune system towards the virus for devising various measures involved in diagnostics, prevention as well as therapeutics which would collectively help in controlling the infection. Nanotechnology-based approaches which have been commonly used in diagnostics and treatment of other viral diseases can prove to be a promising approach in controlling COVID-19 disease. Nanoparticles have shown great potential in various biomedical applications and can prove to be of great use in antiviral therapy as well especially over conventional antiviral agents. Unlike traditional antiviral drugs, nanotechnology-based drugs aid in reducing antiviral resistance due to their unique physico-chemical, mechanical as well as opto-electronic properties. Furthermore, use of nanotechnology-based antiviral drugs in the current pandemic situation is preferred over traditional antiviral therapy due to its easy synthesis, convenient modulation of properties, high stability, inertness, low cytotoxicity, cost effective nature, etc. We have elaborated upon action of different nanoparticles such as metal and metal oxide nanoparticles, carbon-based nanoparticles, quantum dots, polymeric nanoparticles and lipid-based nanoparticles upon various viruses along with its antiviral mechanism and how they can be exploited in controlling the spread of SARSCoV-2 by understanding the pathophysiology of the virus in causing COVID-19 disease. With the world's attention on COVID-19 vaccine development, several candidates have exploited nanotechnology-based approaches while developing vaccines against SARS-CoV-2. However, these are still under clinical trials and it is yet to be seen which vaccines gets approval to be released into the international markets.

However, it is important to consider some of the crucial shortcomings associated with use of nanotechnologybased drugs in antiviral therapy. Firstly, specific targeting at a defined location is necessary for which receptor-based nanoparticles should be used ensuring nano-systems particularly damage the specific viruses. Secondly, there is need to pay attention to surface functionalization of nanoparticles to be used as antiviral agents so as to make sure that these functionalized nanoparticles reach the target location and act against the viruses without being cleared by the immune system. Thirdly, biocompatible nature of these nanoparticles upon interaction with the host cells needs to be considered, as these nanoparticles should only act against the viruses and not the host cells, thus minimizing the associated side effects. Fourthly, efficacy of nanoparticles along with conventional antiviral drugs needs to be standardized for use in antiviral therapy in concentration and time-dependent manner. Lastly, multi-faceted focus is needed to consider various aspects such as different categories of viruses, their variability, mutable nature, associated antiviral drugs and its response when used in vivo to use such nanotechnologybased antiviral agents particularly in the current pandemic situation. Thus, nanotechnology can help us tackle COVID19 disease by development of specific treatment by minimizing the associated shortcomings thereby revolutionizing our fight against SARS-CoV-2 infection. However, it needs to be noted that these nanotechnology-based approaches help the immunity in eliminating SARS-CoV-2 from human body. The main function is performed by human immune system for combatting COVID-19 disease which is in turn influenced by various factors like age, sex, lifestyle, nutrition, co-morbidities, etc., but it would need further studies for detailed understanding.

\section{Declarations}

Conflict of interest There are no conflicts to declare.

\section{References}

Abdul W, Muhammad A, Ullah KA, Asmat A, Abdul B (2020) Role of nanotechnology in diagnosing and treating COVID-19 during the pandemic. Int J Clin Virol 4:065-070. https://doi.org/10.2932/ journal.ijcv.1001017

Abo-zeid Y, Ismail NS, McLean GR, Hamdy NM (2020) A molecular docking study repurposes FDA approved iron oxide nanoparticles to treat and control COVID-19 infection. Eur J Pharm Sci 153:105465. https://doi.org/10.1016/j.ejps.2020.105465

Agarwal HK, Chhikara BS, Doncel GF, Parang K (2017) Synthesis and anti-HIV activities of unsymmetrical long chain dicarboxylate esters of dinucleoside reverse transcriptase inhibitors. Bioorg Med Chem Lett 27:1934-1937. https://doi.org/10.1016/j.bmcl. 2017.03.031

Agostini ML, Andres EL, Sims AC, Graham RL, Sheahan TP, Lu X, Smith EC, Case JB, Feng JY, Jordan R, Ray AS, Cihlar T, Siegal D, Mackman RL, Clarke MO, Baric RS, Denison MR (2018) Coronavirus susceptibility to the antiviral remdesivir (GS-5734) is mediated by the viral polymerase and the proofreading exoribonuclease. Mbio 9:e00221-e318. https://doi.org/10.1128/mBio. 00221-18

Aguiar ACC, Murce E, Cortopassi WA, Pimentel AS, Almeida MMFS, Barros DCS, Guedes JS, Meneghetti MR, Krettli AU (2018) Chloroquine analogs as antimalarial candidates with potent in vitro and in vivo activity. Int J Parasitol Drugs Drug Resist 8:459-464. https://doi.org/10.1016/j.ijpddr.2018.10.002

Ahmed SF, Quadeer AA, McKay MR (2020) Preliminary identification of potential vaccine targets for the COVID-19 coronavirus (SARS-CoV-2) based on SARS-CoV immunological studies. Viruses 12:254. https://doi.org/10.3390/v12030254 
Alex MRA, Chacko AJ, Jose S, Souto EB (2011) Lopinavir loaded solid lipid nanoparticles (SLN) for intestinal lymphatic targeting. Eur J Pharm Sci 42:11-18. https://doi.org/10.1016/j.ejps. 2010.10.002

Al-Horani RA, Kar S, Aliter KF (2020) Potential anti-COVID-19 therapeutics that block the early stage of the viral life cycle: structures, mechanisms, and clinical trials. Int J Mol Sci 21:5224. https:// doi.org/10.3390/ijms21155224

Aliyev E, Filiz V, Khan MM, Lee YJ, Abetz C, Abetz V (2019) Structural characterization of graphene oxide: surface functional groups and fractionated oxidative debris. Nanomaterials 9:1180. https://doi.org/10.3390/nano9081180

Almeida AJ, Souto E (2007) Solid lipid nanoparticles as a drug delivery system for peptides and proteins. Adv Drug Deliv Rev 59:478-490. https://doi.org/10.1016/j.addr.2007.04.007

Alshehri R, Ilyas AM, Hasan A, Arnaout A, Ahmed F, Memic A (2016) Carbon nanotubes in biomedical applications: factors, mechanisms, and remedies of toxicity. J Med Chem 59:8149-8167. https://doi.org/10.1021/acs.jmedchem.5b01770

Andresen H, Mager M, Grießner M, Charchar P, Todorova N, Bell N, Theocharidis G, Bertazzo S, Yarovsky I, Stevens MM (2014) Single-step homogeneous immunoassays utilizing epitope-tagged gold nanoparticles: on the mechanism, feasibility, and limitations. Chem Mater 26:4696-4704. https://doi.org/10.1021/cm500 $535 \mathrm{p}$

Ankamwar B (2020) Gold and silver nanoparticles used for SERS detection of S. aureus and E. coli. Nano Express 1:010020. https://doi.org/10.1088/2632-959x/ab85b4

Ankamwar B, Gharpure S (2019) Non-antibacterial biogenic gold nanoparticles an ulterior drug carrier. Mater Res Express 6:1050c7. https://doi.org/10.1088/2053-1591/ab429f

Ankamwar B, Sur UK, Das P (2016) SERS study of bacteria using biosynthesized silver nanoparticles as the SERS substrate. Anal Methods 8:2335-2340. https://doi.org/10.1039/c5ay03014e

Antoine TE, Hadigal SR, Yakoub AM, Mishra YK, Bhattacharya P, Haddad C, Valyi-Nagy T, Adelung R, Prabhakar BS, Shukla D (2016) Intravaginal zinc oxide tetrapod nanoparticles as novel immunoprotective agents against genital herpes. J Immunol 196:4566-4575. https://doi.org/10.4049/jimmunol.1502373

Arakha M, Pal S, Samantarrai D, Panigrahi TK, Mallick BC, Pramanik K, Mallick B, Jha S (2015) Antimicrobial activity of iron oxide nanoparticle upon modulation of nanoparticle-bacteria interface. Sci Rep 5:14813. https://doi.org/10.1038/srep14813

Astuti I, Ysrafil Y (2020) Severe acute respiratory syndrome coronavirus 2 (SARS-CoV-2): an overview of viral structure and host response. Diabetes Metab Syndr Clin Res Rev 14:407-412. https://doi.org/10.1016/j.dsx.2020.04.020

Báez-Santos YM, St John SE, Mesecar AD (2015) The SARS-coronavirus papain-like protease: structure, function and inhibition by designed antiviral compounds. Antiviral Res 115:21-38. https:// doi.org/10.1016/j.antiviral.2014.12.015

Bakry R, Vallant RM, Najam-ul-Haq M, Rainer M, Szabo Z, Huck CW, Bonn GK (2007) Medicinal applications of fullerenes. Int J Nanomed 2:639-649

Baram-Pinto D, Shukla S, Gedanken A, Sarid R (2010) Inhibition of HSV-1 attachment, entry and cell-to-cell spread by functionalized multivalent gold nanoparticles. Small 6:1044-1050. https:// doi.org/10.1002/smll.200902384

Barras A, Pagneux Q, Sane F, Wang Q, Boukherroub R, Hober D, Szunerits S (2016) High efficiency of functional carbon nanodots as entry inhibitors of herpes simplex virus type 1. ACS Appl Mater Interfaces 8:9004-9013. https://doi.org/10.1021/acsami. $6 \mathrm{~b} 01681$

Battaglia L, Ugazio E (2019) Lipid nano- and microparticles: an overview of patent-related research. J Nanomater 2019:2834941. https://doi.org/10.1155/2019/2834941
Bekyarova E, Ni Y, Malarkey EB, Montana V, McWilliams JL, Haddon RC, Parpura V (2006) Applications of carbon nanotubes in biotechnology and biomedicine. J Biomed Nanotechnol 1:3-17. https://doi.org/10.1166/jbn.2005.004

Bertram S, Glowacka I, Müller MA, Lavender H, Gnirss K, Nehlmeier I, Niemeyer D, He Y, Simmons G, Drosten C, Soilleux EJ, Jahn O, Steffen I, Pohlmann F (2011) Cleavage and activation of the severe acute respiratory syndrome coronavirus spike protein by human airway trypsin-like protease. J Virol 85:13363-13372. https://doi.org/10.1128/jvi.05300-11

Beyerle A, Braun A, Banerjee A, Ercal N, Eickelberg O, Kissel TH, Stoeger T (2011) Inflammatory responses to pulmonary application of PEI-based siRNA nanocarriers in mice. Biomaterials 32:8694-8701. https://doi.org/10.1016/j.biomaterials.2011.07. 082

Bouazzaoui A, Abdellatif AA, Al-Allaf FA, Bogari NM, Al-Dehlawi S, Qari SH (2021) Strategies for vaccination: conventional vaccine approaches versus new-generation strategies in combination with adjuvants. Pharmaceutics 13(2):140

Bowman MC, Ballard TE, Ackerson CJ, Feldheim DL, Margolis DM, Melander C (2008) Inhibition of HIV fusion with multivalent gold nanoparticles. J Am Chem Soc 130:6896-6897. https://doi. org/10.1021/ja710321g

Bromberg L, Bromberg DJ, Hatton TA, Bandín I, Concheiro A, Alvarez-Lorenzo C (2012) Antiviral properties of polymeric aziridine- and biguanide-modified core-shell magnetic nanoparticles. Langmuir 28:4548-4558. https://doi.org/10.1021/la205127x

Bruchez M, Moronne M, Gin P, Weiss S, Alivisatos AP (1998) Semiconductor nanocrystals as fluorescent biological labels. Science 281(5385):2013-2016

Cagno V, Andreozzi P, D’Alicarnasso M, Silva PJ, Mueller M, Galloux M, Le Goffic R, Jones ST, Vallino M, Hodek J, Weber J, Sen S, Janecek ER, Bekdemir A, Sanavio B, Martinelli C, Donalisio M, Welti MAR, Eleouet JF, Han Y, Kaiser L, Vokovic L, Tapparel C, Kral P, Krol S, Lembo D, Stellacci F (2018) Broad-spectrum non-toxic antiviral nanoparticles with a virucidal inhibition mechanism. Nat Mater 17:195-203. https://doi.org/10.1038/ NMAT5053

Caly L, Druce JD, Catton MG, Jans DA, Wagstaff KM (2020) The FDA-approved drug ivermectin inhibits the replication of SARSCoV-2 in vitro. Antiviral Res 178:104787. https://doi.org/10. 1016/j.antiviral.2020.104787

Calzoni E, Cesaretti A, Polchi A, Di Michele A, Tancini B, Emiliani C (2019) Biocompatible polymer nanoparticles for drug delivery applications in cancer and neurodegenerative disorder therapies. J Funct Biomater 10:4. https://doi.org/10.3390/jfb10010004

Campos EVR, Pereira AES, De Oliveira JL, Carvalho LB, GuilgerCasagrande M, De Lima R, Fraceto LF (2020) How can nanotechnology help to combat COVID-19? Opportunities and urgent need. J Nanobiotechnol 18:125. https://doi.org/10.1186/ s12951-020-00685-4

Cardoso VMO, Moreira BJ, Comparetti EJ, Sampaio I, Ferreira LMB, Lins PMP, Zucolotto V (2020) Is nanotechnology helping in the fight against COVID-19? Front Nanotechnol 2:4. https://doi.org/ 10.3389/FNANO.2020.588915

Cavalli R, Donalisio M, Civra A, Ferruti P, Ranucci E, Trotta F, Lembo D (2009) Enhanced antiviral activity of Acyclovir loaded into $\beta$-cyclodextrin-poly(4-acryloylmorpholine) conjugate nanoparticle. J Control Release 137:116-122. https://doi.org/10.1016/j. jconrel.2009.04.004

Cavezzi A, Troiani E, Corrao S (2020) COVID-19: hemoglobin, iron, and hypoxia beyond inflammation. A narrative review. Clin Pract 10:1271. https://doi.org/10.4081/cp.2020.1271

Chakravarty M, Vora A (2020) Nanotechnology-based antiviral therapeutics. Drug Deliv Transl Res. https://doi.org/10.1007/ s13346-020-00818-0

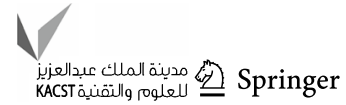


Chan WCW (2020) Nano research for COVID-19. ACS Nano 14:3719_ 3720. https://doi.org/10.1021/acsnano.0c02540

Chan WC, Maxwell DJ, Gao X, Bailey RE, Han M (2002) Luminescent quantum dots for multiplexed biological detection and imaging. Curr Opin Biotechnol 13(1):40-46

Chattopadhyay N, Zastre J, Wong HL, Wu XY, Bendayan R (2008) Solid lipid nanoparticles enhance the delivery of the HIV protease inhibitor, atazanavir, by a human brain endothelial cell line. Pharm Res 25:2262-2271. https://doi.org/10.1007/ s11095-008-9615-2

Chauhan G, Madou MJ, Kalra S, Chopra V, Ghosh D (2020) Nanotechnology for COVID-19: therapeutics and vaccine research. ACS Nano 14:7760-7782. https://doi.org/10.1021/acsnano.0c04006

Chen L, Liang J (2020) An overview of functional nanoparticles as novel emerging antiviral therapeutic agents. Mater Sci Eng C 112:110924. https://doi.org/10.1016/j.msec.2020.110924

Chen X, Han W, Wang G, Zhao X (2020) Application prospect of polysaccharides in the development of anti-novel coronavirus drugs and vaccines. Int J Biol Macromol 164:331-343. https:// doi.org/10.1016/j.ijbiomac.2020.07.106

Chhikara BS, Rathi B, Singh J (2020) Corona virus SARS-CoV-2 disease COVID-19: infection, prevention and clinical advances of the prospective chemical drug therapeutics. Chem Biol Lett 7(1):63-72

Chuan J, Li Y, Yang L, Sun X, Zhang Q, Gong T, Zhang Z (2013) Enhanced rifampicin delivery to alveolar macrophages by solid lipid nanoparticles. J Nanoparticle Res 15:1634. https://doi.org/ 10.1007/s11051-013-1634-1

Croci R, Bottaro E, Chan KWK, Watanabe S, Pezzullo M, Mastrangelo E, Nastruzzi C (2016) Liposomal systems as nanocarriers for the antiviral agent ivermectin. Int J Biomater 2016:8043983. https:// doi.org/10.1155/2016/8043983

Cui X, Xu S, Wang X, Chen C (2018) The nano-bio interaction and biomedical applications of carbon nanomaterials. Carbon 138:436-450. https://doi.org/10.1016/j.carbon.2018.07.069

da Silva MA, Battistel AP, Teixeira HF, Volpato NM (2020) Development of nanoemulsions containing penciclovir for herpes simplex treatment and a liquid chromatographic method to drug assessment in porcine skin layers. Drug Anal Res 4:22-27. https://doi. org/10.2245/2527-2616.103121

de Haan CAM, Rottier PJM (2005) Molecular interactions in the assembly of coronaviruses. Adv Virus Res 64:165-230. https:// doi.org/10.1016/S0065-3527(05)64006-7

de Gusseme B, Sintubin L, Baert L, Thibo E, Hennebel T, Vermeulen G, Uyttendaele M, Verstraete W, Boon N (2010) Biogenic silver for disinfection of water contaminated with viruses. Appl Environ Microbiol 76:1082-1087. https://doi.org/10.1128/AEM. 02433-09

Donders F, Lonnée-Hoffmann R, Tsiakalos A, Mendling W, De Oliveira JM, Judlin P, Xue F, Donders GGG (2020) ISIDOG recommendations concerning COVID-19 and pregnancy. Diagnostics 10:243. https://doi.org/10.3390/diagnostics10040243

Dong X, Moyer MM, Yang F, Sun YP, Yang L (2017) Carbon dots' antiviral functions against noroviruses. Sci Rep 7:519. https:// doi.org/10.1038/s41598-017-00675-x

Donskyi IS, Azab W, Cuellar-Camacho JL, Guday G, Lippitz A, Unger WES, Osterrieder K, Adeli M, Haag R (2019) Functionalized nanographene sheets with high antiviral activity through synergistic electrostatic and hydrophobic interactions. Nanoscale 11:15804-15809. https://doi.org/10.1039/c9nr05273a

Du T, Liang J, Dong N, Liu L, Fang L, Xiao S, Han H (2016) Carbon dots as inhibitors of virus by activation of type I interferon response. Carbon 110:278-285. https://doi.org/10.1016/j.carbon. 2016.09.032

Du T, Liang J, Dong N, Lu J, Fu Y, Fang L, Xiao S, Han H (2018) Glutathione-capped $\mathrm{Ag}_{2} \mathrm{~S}$ nanoclusters inhibit coronavirus proliferation through blockage of viral RNA synthesis and budding. ACS Appl Mater Interfaces 10:4369-4378. https:// doi.org/10.1021/acsami.7b13811

Eatemadi A, Daraee H, Karimkhanloo H, Kouhi M, Zarghami N, Akbarzadeh A, Abasi M, Hanifehpour Y, Joo SW (2014) Carbon nanotubes: properties, synthesis, purification, and medical applications. Nanoscale Res Lett 9:393. https://doi.org/10. 1186/1556-276X-9-393

Eby GA (1997) Zinc ion availability-the determinant of efficacy in zinc lozenge treatment of common colds. J Antimicrob Chemother 40:483-493. https://doi.org/10.1093/oxfordjournals.jac. a020864

Elbaz NM, Ziko L, Siam R, Mamdouh W (2016) Core-shell silver/ polymeric nanoparticles-based combinatorial therapy against breast cancer in-vitro. Sci Rep 6:30729. https://doi.org/10.1038/ srep30729

Elechiguerra JL, Burt JL, Morones JR, Camacho-Bragado A, Gao X, Lara HH, Yacaman MJ (2005) Interaction of silver nanoparticles with HIV-1. J Nanobiotechnol 3:6. https://doi.org/10.1186/ 1477-3155-3-6

El-Gizawy SA, El-Maghraby GM, Hedaya AA (2019) Formulation of acyclovir-loaded solid lipid nanoparticles: design, optimization, and in-vitro characterization. Pharm Dev Technol 24:1287-1298. https://doi.org/10.1080/10837450.2019.1667385

El-Say KM, El-Sawy HS (2017) Polymeric nanoparticles: promising platform for drug delivery. Int J Pharm 528:675-691. https://doi. org/10.1016/j.ijpharm.2017.06.052

Figueroa SM, Veser A, Abstiens K, Fleischmann D, Beck S, Goepferich A (2019) Influenza A virus mimetic nanoparticles trigger selective cell uptake. Proc Natl Acad Sci 116:9831-9836. https:// doi.org/10.1073/pnas.1902563116

Friedman SH, DeCamp DL, Kenyon GL, Sijbesma RP, Srdanov G, Wudl F (1993) Inhibition of the HIV-1 protease by fullerene derivatives: model building studies and experimental verification. J Am Chem Soc 115:6506-6509. https://doi.org/10.1021/ ja00068a005

Galdiero S, Falanga A, Vitiello M, Cantisani M, Marra V, Galdiero M (2011) Silver nanoparticles as potential antiviral agents. Molecules 16:8894-8918. https://doi.org/10.3390/molecules16108894

García-Pinel B, Porras-Alcalá C, Ortega-Rodríguez A, Sarabia F, Prados J, Melguizo C, López-Romero JM (2019) Lipid-based nanoparticles: application and recent advances in cancer treatment. Nanomaterials 9(4):638. https://doi.org/10.3390/nano9040638

Ge Q, Filip L, Bai A, Nguyen T, Eisen HN, Chen J (2004) Inhibition of influenza virus production in virus-infected mice by RNA interference. Proc Natl Acad Sci 101:8676-8681. https://doi.org/10. 1073/pnas.0402486101

Ghaffari H, Tavakoli A, Moradi A, Tabarraei A, Bokharaei-Salim F, Zahmatkeshan M, Farahmand M, Javanmard D, Kiani SJ, Esghaei M, Pirhajati-Mahabadi V, Monavari SH, AtaeiPirkooh A (2019) Inhibition of H1N1 influenza virus infection by zinc oxide nanoparticles: another emerging application of nanomedicine. J Biomed Sci 26:70. https://doi.org/10.1186/ s12929-019-0563-4

Gharpure S, Ankamwar B (2020) Synthesis and antimicrobial properties of zinc oxide nanoparticles. J Nanosci Nanotechnol 20:59775996. https://doi.org/10.1166/jnn.2020.18707

Gharpure S, Akash A, Ankamwar B (2019a) A review on antimicrobial properties of metal nanoparticles. J Nanosci Nanotechnol 20:3303-3339. https://doi.org/10.1166/jnn.2020.17677

Gharpure S, Kirtiwar S, Palwe S, Akash A, Ankamwar B (2019b) Non-antibacterial as well as non-anticancer activity of flower extract and its biogenous silver nanoparticles. Nanotechnology 30:195701. https://doi.org/10.1088/1361-6528/ab011a

Gharpure S, Jadhav T, Ghotekar C, Jagtap A, Vare Y, Ankamwar B (2021a) Non-antibacterial and antibacterial $\mathrm{ZnO}$ nanoparticles 
composed of different surfactants. J Nanosci Nanotechnol 21:5905-5919. https://doi.org/10.1166/jnn.2021.19513

Gharpure S, Yadwade R, Mehmood S, Ankamwar B (2021b) Antibacterial activities of biosynthesized $\mathrm{ZnO}$ nanoparticles using leaf and fruit extracts of Neolamarckia cadamba. J Nanosci Nanotechnol 21:1-15. https://doi.org/10.1166/jnn.2021.19538 Gurunathan S, Qasim M, Park C, Yoo H, Choi D, Song H, Park C, Kim JH, Hong K (2018) Cytotoxicity and transcriptomic analysis of silver nanoparticles in mouse embryonic fibroblast cells. Int J Mol Sci 19:3618. https://doi.org/10.3390/ijms19113618

Gurunathan S, Qasim M, Choi Y, Do JT, Park C, Hong K, Kim JH, Song H (2020) Antiviral potential of nanoparticles-can nanoparticles fight against coronaviruses? Nanomaterials 10:1645. https://doi.org/10.3390/nano10091645

Han YS, Chang GG, Juo CG, Lee HJ, Yen SH, Hsu JTA, Chen X (2005) Papain-like protease 2 (PLP2) from severe acute respiratory syndrome coronavirus (SARS-CoV): expression, purification, characterization, and inhibition. Biochemistry 44:10349-10359. https://doi.org/10.1021/bi0504761

Hennig R, Veser A, Kirchhof S, Goepferich A (2015) Branched polymer-drug conjugates for multivalent blockade of angiotensin II receptors. Mol Pharm 12:3292-3302. https://doi.org/10.1021/ acs.molpharmaceut.5b00301

Hoffmann M, Kleine-Weber H, Pöhlmann S (2020a) A multibasic cleavage site in the spike protein of SARS-CoV-2 is essential for infection of human lung cells. Mol Cell 78:779-784.e5. https://doi.org/10.1016/j.molcel.2020.04.022

Hoffmann M, Kleine-Weber H, Schroeder S, Krüger N, Herrler T, Erichsen S, Schiergens TS, Herrler G, Wu NH, Nitsche A, Müller MA, Drosten C, Pohlmann F (2020b) SARS-CoV-2 cell entry depends on ACE2 and TMPRSS2 and is blocked by a clinically proven protease inhibitor. Cell 181:271-280.e8. https://doi.org/10.1016/j.cell.2020.02.052

Hsu JTA, Kuo CJ, Hsieh HP, Wang YC, Huang KK, Lin CPC, Huang PF, Chen X, Liang PH (2004) Evaluation of metal-conjugated compounds as inhibitors of 3CL protease of SARS-CoV. FEBS Lett 574:116-120. https://doi.org/10.1016/j.febslet.2004.08. 015

Hu X, Mu L, Wen J, Zhou Q (2012) Covalently synthesized graphene oxide-aptamer nanosheets for efficient visible-light photocatalysis of nucleic acids and proteins of viruses. Carbon 50:2772-2781. https://doi.org/10.1016/j.carbon.2012.02.038

Hu CM, Chang WS, Fang ZS, Chen YT, Wang WL, Tsai HH, Chueh LL, Takano T, Hohdatsu T, Chen HW (2017) Nanoparticulate vacuolar ATPase blocker exhibits potent host-targeted antiviral activity against feline coronavirus. Sci Rep 7:13043

Hu CMJ, Chen YT, Fang ZS, Chang WS, Chen HW (2018) Antiviral efficacy of nanoparticulate vacuolar ATPase inhibitors against influenza virus infection. Int J Nanomed 13:8579-8593. https:// doi.org/10.2147/IJN.S185806

Huang X, Li M, Xu Y, Zhang J, Meng X, An X, Sun L, Guo L, Shan X, Ge J, Chen J, Luo Y, Wu H, Zhang Y, Jiang Q, Ning $X$ (2019) Novel gold nanorod-based HR1 peptide inhibitor for middle east respiratory syndrome coronavirus. ACS Appl Mater Interfaces 11:19799-19807. https://doi.org/10.1021/ acsami.9b04240

Hussain S, Ji Z, Taylor AJ, DeGraff LM, George M, Tucker CJ, Chang CH, Li R, Bonner JC, Garantziotis S (2016) Multiwalled carbon nanotube functionalization with high molecular weight hyaluronan significantly reduces pulmonary injury. ACS Nano 10:76757688. https://doi.org/10.1021/acsnano.6b03013

Iannazzo D, Pistone A, Galvagno S, Ferro S, De Luca L, Monforte AM, Da Ros T, Hadad C, Prato M, Pannecouque C (2015) Synthesis and anti-HIV activity of carboxylated and drug-conjugated multiwalled carbon nanotubes. Carbon 82:548-561. https://doi.org/10. 1016/j.carbon.2014.11.007
Ibrahim KS (2013) Carbon nanotubes-properties and applications: a review. Carbon Lett 14:131-144. https://doi.org/10.5714/cl.2013. 14.3.131

Innocenzi P, Stagi L (2020) Carbon-based antiviral nanomaterials: graphene, C-dots, and fullerenes. A perspective. Chem Sci 11:66066622. https://doi.org/10.1039/d0sc02658a

Ishida $\mathrm{T}$ (2018) Antiviral activities of $\mathrm{Cu}^{2+}$ ions in viral prevention, replication, RNA degradation, and for antiviral efficacies of lytic virus, ROS-mediated virus, copper chelation. World Sci News 99:148-168

Ishida $\mathrm{T}$ (2019) Review on the role of $\mathrm{Zn}^{2+}$ ions in viral pathogenesis and the effect of $\mathrm{Zn}^{2+}$ ions for host cell-virus growth inhibition. Am J Biomed Sci Res 2:28-37. https://doi.org/10.34297/ajbsr. 2019.02.000566

Jain S, Mistry MA, Swarnakar NK (2011) Enhanced dermal delivery of acyclovir using solid lipid nanoparticles. Drug Deliv Transl Res 1:395-406. https://doi.org/10.1007/s13346-011-0036-0

Jang H, Kim YK, Kwon HM, Yeo WS, Kim DE, Min DH (2010) A graphene-based platform for the assay of duplex-DNA unwinding by helicase. Angew Chem 122:5839-5843. https://doi.org/ 10.1002/ange.201001332

Jang H, Ryoo SR, Kim YK, Yoon S, Kim H, Han SW, Choi BS, Kim DE, Min DH (2013) Discovery of hepatitis C virus NS3 helicase inhibitors by a multiplexed, high-throughput helicase activity assay based on graphene oxide. Angew Chem Int Ed 52:2340 2344. https://doi.org/10.1002/anie.201209222

Jeremiah SS, Miyakawa K, Morita T, Yamaoka Y, Ryo A (2020) Potent antiviral effect of silver nanoparticles on SARS-CoV-2. Biochem Biophys Res Commun 533:195-200. https://doi.org/10.1016/j. bbrc.2020.09.018

Jiang J, Pi J, Cai J (2018) The advancing of zinc oxide nanoparticles for biomedical applications. Bioinorg Chem Appl 2018:1062562. https://doi.org/10.1155/2018/1062562

Kampf G, Todt D, Pfaender S, Steinmann E (2020) Persistence of coronaviruses on inanimate surfaces and their inactivation with biocidal agents. J Hosp Infect 104:246-251. https://doi.org/10. 1016/j.jhin.2020.01.022

Kasouni A, Chatzimitakos T, Stalikas C (2019) Bioimaging applications of carbon nanodots: a review. C J Carbon Res 5:19. https:// doi.org/10.3390/c5020019

Kaur SP, Gupta V (2020) COVID-19 vaccine: a comprehensive status report. Virus Res 13:198114. https://doi.org/10.1016/j.virusres. 2020.198114

Khailany RA, Safdar M, Ozaslan M (2020) Genomic characterization of a novel SARS-CoV-2. Gene Rep 19:100682. https://doi.org/ 10.1016/j.genrep.2020.100682

Khalid HF, Tehseen B, Sarwar Y, Hussain SZ, Khan WS, Raza ZA, Bajwa SZ, Kanaras AG, Hussain I, Rehman A (2019) Biosurfactant coated silver and iron oxide nanoparticles with enhanced anti-biofilm and anti-adhesive properties. J Hazard Mater 364:441-448. https://doi.org/10.1016/j.jhazmat.2018.10.049

Khurana A, Allawadhi P, Khurana I, Allwadhi S, Weiskirchen R, Banothu AK, Chhabra D, Joshi K, Bharani KK (2021) Role of nanotechnology behind the success of mRNA vaccines for COVID19. Nano Today $38: 101142$

Kim JY, Lee C, Love DC, Sedlak DL, Yoon J, Nelson KL (2011) Inactivation of MS2 coliphage by ferrous ion and zero-valent iron nanoparticles. Environ Sci Technol 45(16):6978-6984. https:// doi.org/10.1021/es201345y

Kirtiwar S, Gharpure S, Ankamwar B (2018) Effect of nutrient media on antibacterial activity of silver nanoparticles synthesized using Neolamarckia cadamba. J Nanosci Nanotechnol 19:1923-1933. https://doi.org/10.1166/jnn.2019.16117

Koller LD, Mulhern SA, Frankel NC, Steven MG, Williams JR (1987) Immune dysfunction in rats fed a diet deficient in copper. Am J Clin Nutr 45:997-1006. https://doi.org/10.1093/ajen/45.5.997

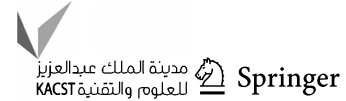


Kolyvushko O, Latzke J, Dahmani I, Osterrieder N, Chiantia S, Azab W (2020) Differentially-charged liposomes interact with alphaherpesviruses and interfere with virus entry. Pathogens 9:359. https://doi.org/10.3390/pathogens9050359

Krishnaraj R, Chandran S, Pal P, Berchmans S (2014) Investigations on the antiretroviral activity of carbon nanotubes using computational molecular approach. Comb Chem High Throughput Screen 17:531-535. https://doi.org/10.2174/138620731766614 0116110558

Kulkarni CV (2012) Lipid crystallization: from self-assembly to hierarchical and biological ordering. Nanoscale 4:5779-5791. https:// doi.org/10.1039/c2nr31465g

Kumar S, Rathi B (2020) Coronavirus disease COVID-19: a new threat to public health. Curr Top Med Chem 20:599-600. https://doi. org/10.2174/1568026620999200305144319

Kumar R, Dhanawat M, Kumar S, Singh BN, Pandit JK, Sinha VR (2014) Carbon nanotubes: a potential concept for drug delivery applications. Recent Patents Drug Deliv Formul 8:12-26

Kumar R, Nayak M, Sahoo GC, Pandey K, Sarkar MC, Ansari Y, Das VNR, Topno RK, Madhukar M, Das P (2019) Iron oxide nanoparticles based antiviral activity of H1N1 influenza A virus. J Infect Chemother 25:325-329. https://doi.org/10.1016/j.jiac. 2018.12.006

Kyriakidis NC, López-Cortés A, González EV, Grimaldos AB, Prado EO (2021) SARS-CoV-2 vaccines strategies: a comprehensive review of phase 3 candidates. NPJ Vaccines. 6(1):28

Lategan K, Alghadi H, Bayati M, de Cortalezzi M, Pool E (2018) Effects of graphene oxide nanoparticles on the immune system biomarkers produced by RAW 264.7 and human whole blood cell cultures. Nanomaterials 8:125. https://doi.org/10.3390/nano8 020125

Lee C (2015) Porcine epidemic diarrhea virus: an emerging and reemerging epizootic swine virus. Virol J 12:193. https://doi.org/ 10.1186/s12985-015-0421-2

Li F, Li W, Farzan M, Harrison SC (2005) Structural biology: structure of SARS coronavirus spike receptor-binding domain complexed with receptor. Science 309:1864-1868. https://doi.org/10.1126/ science. 1116480

Linder MC, Hazegh-Azam M (1996) Copper biochemistry and molecular biology. Am J Clin Nutr 63:797S-811S. https://doi.org/10. 1093/ajcn/63.5.797

Liu DX, Fung TS, Chong KKL, Shukla A, Hilgenfeld R (2014) Accessory proteins of SARS-CoV and other coronaviruses. Antiviral Res 109:97-109. https://doi.org/10.1016/j.antiviral.2014.06.013

Liu J, Cao R, Xu M, Wang X, Zhang H, Hu H, Li Y, Hu Z, Zhong W, Wang M (2020a) Hydroxychloroquine, a less toxic derivative of chloroquine, is effective in inhibiting SARS-CoV-2 infection in vitro. Cell Discov 6:1-4. https://doi.org/10.1038/ s41421-020-0156-0

Liu T, Luo S, Libby P, Shi GP (2020b) Cathepsin L-selective inhibitors: a potentially promising treatment for COVID-19 patients. Pharmacol Ther 213:107587. https://doi.org/10.1016/j.pharm thera.2020.107587

Łoczechin A, Séron K, Barras A, Giovanelli E, Belouzard S, Chen YT, Metzler-Nolte N, Boukherroub R, Dubuisson J, Szunerits $S$ (2019) Functional carbon quantum dots as medical countermeasures to human coronavirus. ACS Appl Mater Interfaces 11:42964-42974. https://doi.org/10.1021/acsami.9b15032

Lu H (2020) Drug treatment options for the 2019-new coronavirus (2019-nCoV). Biosci Trends 14:69-71. https://doi.org/10.5582/ BST.2020.01020

Lu R, Zhao X, Li J, Niu P, Yang B, Wu H, Wang W, Song H, Huang B, Zhu N, Bi Y, Ma X, Zhan F, Wang L, Hu T, Zhou H, Hu Z, Zhou W, Zhao L, Chen J, Meng Y, Wang J, Lin Y, Yuan J, Xie Z, Ma J, Liu WJ, Wang D, Xu W, Holmes EC, Gao GF, Wu G, Chen W, Shi W, Tan W (2020) Genomic characterisation and epidemiology of 2019 novel coronavirus: implications for virus origins and receptor binding. Lancet 395:565-574. https://doi. org/10.1016/S0140-6736(20)30251-8

Mainardes RM, Diedrich C (2020) The potential role of nanomedicine on COVID-19 therapeutics. Ther Deliv 11:411-414. https://doi. org/10.4155/tde-2020-0069

Maiti D, Tong X, Mou X, Yang K (2019) Carbon-based nanomaterials for biomedical applications: a recent study. Front Pharmacol 9:1401. https://doi.org/10.3389/fphar.2018.01401

Manivannan S, Ponnuchamy K (2020) Quantum dots as a promising agent to combat COVID-19. Appl Organomet Chem 34(10):e5887. https://doi.org/10.1002/aoc.5887

Martinez ZS, Castro E, Seong CS, Cerón MR, Echegoyen L, Llano M (2016) Fullerene derivatives strongly inhibit HIV-1 replication by affecting virus maturation without impairing protease activity. Antimicrob Agents Chemother 60:5731-5741. https://doi.org/10. 1128/AAC.00341-16

Masters PS (2006) The molecular biology of coronaviruses. Adv Virus Res 65:193-292. https://doi.org/10.1016/S0065-3527(06) 66005-3

Mehendale R, Joshi M, Patravale V (2013) Nanomedicines for treatment of viral diseases. Crit Rev Ther Drug Carrier Syst 30:1-49. https://doi.org/10.1615/CritRevTherDrugCarrierSyst.20130 05469

Mehta P, McAuley DF, Brown M, Sanchez E, Tattersall RS, Manson JJ (2020) COVID-19: consider cytokine storm syndromes and immunosuppression. Lancet 395:1033-1034. https://doi.org/10. 1016/S0140-6736(20)30628-0

Michalet X, Pinaud FF, Bentolila LA, Tsay JM, Doose SJ, Li JJ, Sundaresan G, Wu AM, Gambhir SS, Weiss S (2005) Quantum dots for live cells, in vivo imaging, and diagnostics. Science 307(5709):538-544

Milewska A, Ciejka J, Kaminski K, Karewicz A, Bielska D, Zeglen S, Karolak W, Nowakowska M, Potempa J, Bosch BJ, Pyrc K, Szczubialka K (2013) Novel polymeric inhibitors of HCoV-NL63. Antiviral Res 97:112-121. https://doi.org/10.1016/j.antiviral. 2012.11.006)

Mishra YK, Adelung R, Röhl C, Shukla D, Spors F, Tiwari V (2011) Virostatic potential of micro-nano filopodia-like $\mathrm{ZnO}$ structures against herpes simplex virus-1. Antiviral Res 92:305-312. https://doi.org/10.1016/j.antiviral.2011.08.017

Mishra PK, Mishra H, Ekielski A, Talegaonkar S, Vaidya B (2017) Zinc oxide nanoparticles: a promising nanomaterial for biomedical applications. Drug Discov Today 22:1825-1834. https://doi. org/10.1016/j.drudis.2017.08.006

Moghimi SM, Hunter AC, Murray JC (2005) Nanomedicine: current status and future prospects. FASEB J 19:311-330. https://doi. org/10.1096/fj.04-2747rev

Murray JP, Laband SJ (1979) Degradation of poliovirus by adsorption on inorganic surfaces. Appl Environ Microbiol 37:480-486. https://doi.org/10.1128/aem.37.3.480-486.1979

Nakamura E, Isobe H (2003) Functionalized fullerenes in water. The first 10 years of their chemistry, biology, and nanoscience. Acc Chem Res 36:807-815. https://doi.org/10.1021/ar030027y

Negi JS, Chattopadhyay P, Sharma AK, Ram V (2013) Development of solid lipid nanoparticles (SLNs) of lopinavir using hot self nanoemulsification (SNE) technique. Eur J Pharm Sci 48:231-239. https://doi.org/10.1016/j.ejps.2012.10.022

Nikaeen G, Abbaszadeh S, Yousefinejad S (2020) Application of nanomaterials in treatment, anti-infection and detection of coronaviruses. Nanomedicine 15:1501-1512. https://doi.org/10.2217/ nnm-2020-0117

Noyce JO, Michels H, Keevil CW (2007) Inactivation of influenza A virus on copper versus stainless steel surfaces. Appl Environ Microbiol 73:2748-2750. https://doi.org/10.1128/AEM. 01139-06 
Osman AI, Farrell C, Al-Muhtaseb AH, Harrison J, Rooney DW (2020) The production and application of carbon nanomaterials from high alkali silicate herbaceous biomass. Sci Rep 10:2563. https:// doi.org/10.1038/s41598-020-59481-7

Papp I, Sieben C, Ludwig K, Roskamp M, Böttcher C, Schlecht S, Herrmann A, Haag R (2010) Inhibition of influenza virus infection by multivalent sialic-acid- functionalized gold nanoparticles. Small 6:2900-2906. https://doi.org/10.1002/smll.201001349

Park SJ, Park HH, Kim SY, Kim SJ, Woo K, Ko GP (2014) Antiviral properties of silver nanoparticles on a magnetic hybrid colloid. Appl Environ Microbiol 80:2343-2350. https://doi.org/10.1128/ AEM.03427-13

Park JA, Kim JH, Kang JK, Son JW, Yi IG, Kim SB (2015) Flowthrough experiments for bacteriophage MS2 removal by iron oxide-impregnated fiberglass. Desalin Water Treat 54:23142323. https://doi.org/10.1080/19443994.2014.899521

Partha R, Conyers JL (2009) Biomedical applications of functionalized fullerene-based nanomaterials. Int J Nanomed 4:261-275. https:// doi.org/10.2147/ijn.s5964

Percival SS (1998) Copper and immunity. Am J Clin Nutr 67:1064S-1068S. https://doi.org/10.1093/ajcn/67.5.1064S

Pollock S, Branza Nichita N, Böhmer A, Radulescu C, Dwek RA, Zitzmann N (2010) Polyunsaturated liposomes are antiviral against hepatitis B and C viruses and HIV by decreasing cholesterol levels in infected cells. Proc Natl Acad Sci 107:17176-17181. https://doi.org/10.1073/pnas.1009445107

Puri A, Loomis K, Smith B, Lee JH, Yavlovich A, Heldman E, Blumenthal R (2009) Lipid-based nanoparticles as pharmaceutical drug carriers: from concepts to clinic. Crit Rev Ther Drug Carrier Syst 26:523-580. https://doi.org/10.1615/CritRevTherDrug CarrierSyst.v26.i6.10

Qin T, Ma R, Yin Y, Miao X, Chen S, Fan K, Xi J, Liu Q, Gu Y, Yin Y, Hu J (2019) Catalytic inactivation of influenza virus by iron oxide nanozyme. Theranostics 9:6920-6935. https://doi.org/10. $7150 /$ thno. 35826

Rahman MT, Idid SZ (2020) Can Zn be a critical element in COVID19 treatment? Biol Trace Elem Res. https://doi.org/10.1007/ s12011-020-02194-9

Rai M, Deshmukh SD, Ingle AP, Gupta IR, Galdiero M, Galdiero S (2016) Metal nanoparticles: the protective nanoshield against virus infection. Crit Rev Microbiol 42:46-56. https://doi.org/10. 3109/1040841X.2013.879849

Rasmussen JW, Martinez E, Louka P, Wingett DG (2010) Zinc oxide nanoparticles for selective destruction of tumor cells and potential for drug delivery applications. Expert Opin Drug Deliv 7:1063-1077. https://doi.org/10.1517/17425247.2010.502560

Razzaque MS (2020) COVID-19 pandemic: can maintaining optimal zinc balance enhance host resistance? Tohoku J Exp Med 251:175-181. https://doi.org/10.1620/tjem.251.175

Read SA, Obeid S, Ahlenstiel C, Ahlenstiel G (2019) The role of zinc in antiviral immunity. Adv Nutr 10:696-710. https://doi.org/10. 1093/advances/nmz013

Reynolds N, Dearnley M, Hinton TM (2017) Polymers in the delivery of siRNA for the treatment of virus infections. Top Curr Chem 375:38. https://doi.org/10.1007/s41061-017-0127-6

Rogers JV, Christopher AE, Parkinson V, Ae YWC, Speshock JL, Saber AE, Hussain M (2008) A preliminary assessment of silver nanoparticle inhibition of monkeypox virus plaque formation. Nanoscale Res Lett 3:129-133. https://doi.org/10.1007/ s11671-008-9128-2

Sagripanti JL, Routson LB, Lytle CD (1993) Virus inactivation by copper or iron ions alone and in the presence of peroxide. Appl Environ Microbiol 59:4374-4376

Sametband M, Kalt I, Gedanken A, Sarid R (2014) Herpes simplex virus type-1 attachment inhibition by functionalized graphene oxide. ACS Appl Mater Interfaces 6:1228-1235. https://doi.org/ 10.1021/am405040z

Shankar SS, Rai A, Ankamwar B, Singh A, Ahmad A, Sastry M (2004) Biological synthesis of triangular gold nanoprisms. Nat Mater 3:482-488. https://doi.org/10.1038/nmat 1152

Shen TW, Fromen CA, Kai MP, Luft JC, Rahhal TB, Robbins GR, DeSimone JM (2015) Distribution and cellular uptake of PEGylated polymeric particles in the lung towards cell-specific targeted delivery. Pharm Res 32:3248-3260. https://doi.org/10. 1007/s11095-015-1701-7

Shoji M, Takahashi E, Hatakeyama D, Iwai Y, Morita Y, Shirayama R, Echigo N, Kido H, Nakamura S, Mashino T, Okutani T (2013) Anti-influenza activity of C60 fullerene derivatives. PLoS ONE 8:e66337. https://doi.org/10.1371/journal.pone.0066337

Simmons G, Reeves JD, Rennekamp AJ, Amberg SM, Piefer AJ, Bates $P(2004)$ Characterization of severe acute respiratory syndromeassociated coronavirus (SARS-CoV) spike glycoprotein-mediated viral entry. Proc Natl Acad Sci 101:4240-4245. https://doi. org/10.1073/pnas.0306446101

Singh L, Kruger HG, Maguire GEM, Govender T, Parboosing R (2017) The role of nanotechnology in the treatment of viral infections. Ther Adv Infect Dis 4:105-131. https://doi.org/10.1177/20499 36117713593

Sivasankarapillai VS, Pillai AM, Rahdar A, Sobha AP, Das SS, Mitropoulos AC, Mokarrar MH, Kyzas GZ (2020) On facing the SARS-CoV-2 (COVID-19) with combination of nanomaterials and medicine: possible strategies and first challenges. Nanomaterials 10:852. https://doi.org/10.3390/nano10050852

Song W, Gui M, Wang X, Xiang Y (2018) Cryo-EM structure of the SARS coronavirus spike glycoprotein in complex with its host cell receptor ACE2. PLOS Pathog 14:e1007236. https://doi.org/ 10.1371/journal.ppat.1007236

Song Z, Xu Y, Bao L, Zhang L, Yu P, Qu Y, Zhu H, Zhao W, Han Y, Qin C (2019) From SARS to MERS, thrusting coronaviruses into the spotlight. Viruses 11:59. https://doi.org/10.3390/v11010059

Steinbach JM, Weller CE, Booth CJ, Saltzman WM (2012) Polymer nanoparticles encapsulating siRNA for treatment of HSV-2 genital infection. J Control Release 162:102-110. https://doi.org/10. 1016/j.jconrel.2012.06.008

Tahara K, Kobayashi M, Yoshida S, Onodera R, Inoue N, Takeuchi H (2018) Effects of cationic liposomes with stearylamine against virus infection. Int J Pharm 543:311-317. https://doi.org/10. 1016/j.ijpharm.2018.04.001

Tang Z, Kong N, Zhang X, Liu Y, Hu P, Mou S, Liljeström P, Shi J, Tan W, Kim JS, Cao Y (2020) A materials-science perspective on tackling COVID-19. Nat Rev Mater 5(11):847-860

Taylor R, Hare JP, Abdul-Sada AK, Kroto HW (1990) Isolation, separation and characterisation of the fullerenes C60 and C70: the third form of carbon. J Chem Soc Chem Commun 20:1423-1425. https://doi.org/10.1039/C39900001423

te Velthuis AJW, van den Worm SHE, Sims AC, Baric RS, Snijder EJ, van Hemert MJ (2010) $\mathrm{Zn}^{2+}$ inhibits coronavirus and arterivirus RNA polymerase activity in vitro and zinc ionophores block the replication of these viruses in cell culture. PLoS Pathog 6:e1001176. https://doi.org/10.1371/journal.ppat.1001176

Thi TT, Suys EJ, Lee JS, Nguyen DH, Park KD, Truong NP (2021) Lipid-based nanoparticles in the clinic and clinical trials: from cancer nanomedicine to COVID-19 vaccines. Vaccines 9(4):359

Ting D, Dong N, Fang L, Lu J, Bi J, Xiao S, Han H (2018) Multisite inhibitors for enteric coronavirus: antiviral cationic carbon dots based on curcumin. ACS Appl Nano Mater 1:5451-5459. https:// doi.org/10.1021/acsanm.8b00779

Tooze J, Tooze S, Warren G (1984) Replication of coronavirus MHVA59 in Sac-cells: determination of the first site of budding of progeny virions. Eur J Cell Biol 33:281-293

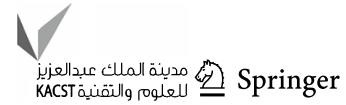


Torchilin V (2009) Multifunctional and stimuli-sensitive pharmaceutical nanocarriers. Eur J Pharm Biopharm 71:431-444. https://doi. org/10.1016/j.ejpb.2008.09.026

Troshina OA, Troshin PA, Peregudov AS, Kozlovskiy VI, Balzarini J, Lyubovskaya RN (2007) Chlorofullerene C60Cl6: a precursor for straightforward preparation of highly water-soluble polycarboxylic fullerene derivatives active against HIV. Org Biomol Chem 5:2783-2791. https://doi.org/10.1039/b705331b

Valdiglesias V, Laffon B (2020) The impact of nanotechnology in the current universal COVID-19 crisis. Let's not forget nanosafety! Nanotoxicology 14(8):1013-1016. https://doi.org/10.1080/17435 390.2020 .1780332

Valizadeh A, Mikaeili H, Samiei M, Farkhani SM, Zarghami N, Akbarzadeh A, Davaran S (2012) Quantum dots: synthesis, bioapplications, and toxicity. Nanoscale Res Lett 7(1):480. https://doi.org/ 10.1186/1556-276X-7-480

Vallabani NVS, Singh S (2018) Recent advances and future prospects of iron oxide nanoparticles in biomedicine and diagnostics. 3 Biotech 8:279. https://doi.org/10.1007/s13205-018-1286-z

van Doremalen N, Bushmaker T, Morris DH, Holbrook MG, Gamble A, Williamson BN, Tamin A, Harcourt JL, Thornburg NJ, Gerber SI, Lloyd-Smith JO, Wit E, Munster VJ (2020) Aerosol and surface stability of SARS-CoV-2 as compared with SARSCoV-1. N Engl J Med 382:1564-1567. https://doi.org/10.1056/ NEJMc2004973

Wang C, Xu L, Liang C, Xiang J, Peng R, Liu Z (2014) Immunological responses triggered by photothermal therapy with carbon nanotubes in combination with anti-CTLA-4 therapy to inhibit cancer metastasis. Adv Mater 26:8154-8162. https://doi.org/10.1002/ adma.201402996

Wang R, Lu KQ, Tang ZR, Xu YJ (2017) Recent progress in carbon quantum dots: synthesis, properties and applications in photocatalysis. J Mater Chem A 5:3717-3734. https://doi.org/10.1039/ c6ta08660h

Warnes SL, Little ZR, Keevil CW (2015) Human coronavirus 229E remains infectious on common touch surface materials. Mbio 6:e01697-e01715. https://doi.org/10.1128/mBio.01697-15

Weber C, Voigt M, Simon J, Danner AK, Frey H, Mailänder V, Helm M, Morsbach S, Landfester K (2019) Functionalization of liposomes with hydrophilic polymers results in macrophage uptake independent of the protein corona. Biomacromol 20:2989-2999. https://doi.org/10.1021/acs.biomac.9b00539

Weiss C, Carriere M, Fusco L, Capua I, Regla-Nava JA, Pasquali M, Scott JA, Vitale F, Unal MA, Mattevi C, Bedognetti D, Merkoci A, Tasciotti E, Yilmazer A, Gogotsi Y, Stellacci F, Delogu LG (2020) Toward nanotechnology-enabled approaches against the COVID-19 pandemic. ACS Nano 14:6383-6406. https://doi.org/ 10.1021/acsnano.0c03697

Wen WH, Lin M, Su CY, Wang SY, Cheng YSE, Fang JM, Wong CH (2009) Synergistic effect of zanamivir-porphyrin conjugates on inhibition of neuraminidase and inactivation of influenza virus. J Med Chem 52:4903-4910. https://doi.org/10.1021/jm900515g

Wrapp D, Wang N, Corbett KS, Goldsmith JA, Hsieh CL, Abiona O, Graham BS, Mclellan JS (2020) Cryo-EM structure of the 2019nCoV spike in the prefusion conformation. Science 367:12601263. https://doi.org/10.1016/S0140-6736(20)30251-8

Xing-Guo Z, Jing M, Min-Wei L, Sai-Ping J, Fu-Qiang H, Yong-Zhong D (2008) Solid lipid nanoparticles loading adefovir dipivoxil for antiviral therapy. J Zhejiang Univ Sci B 9:506-510. https://doi. org/10.1631/jzus.B0820047
Yang N, Shen HM (2020) Targeting the endocytic pathway and autophagy process as a novel therapeutic strategy in COVID-19. Int J Biol Sci 16:1724-1731. https://doi.org/10.7150/ijbs.45498

Yang X, Yang M, Pang B, Vara M, Xia Y (2015) Gold nanomaterials at work in biomedicine. Chem Rev 115:10410-10488. https:// doi.org/10.1021/acs.chemrev.5b00193

Ye S, Shao K, Li Z, Guo N, Zuo Y, Li Q, Lu Z, Chen L, He Q, Han H (2015) Antiviral activity of graphene oxide: how sharp edged structure and charge matter. ACS Appl Mater Interfaces 7:21578-21579. https://doi.org/10.1021/acsami.5b06876

Zacheo A, Hodek J, Witt D, Mangiatordi GF, Ong QK, Kocabiyik O, Depalo N, Fanizza E, Laquintana V, Denora N, Migoni D, Barski P, Stellacci F, Weber J, Krol S (2020) Multi-sulfonated ligands on gold nanoparticles as virucidal antiviral for dengue virus. Sci Rep 10:9052. https://doi.org/10.1038/s41598-020-65892-3

Zazo H, Colino CI, Warzecha KT, Hoss M, Gbureck U, Trautwein C, Tacke F, Lanao JM, Bartneck M (2017) Gold nanocarriers for macrophage-targeted therapy of human immunodeficiency virus. Macromol Biosci 17:1600359. https://doi.org/10.1002/ mabi.201600359

Zheng M, Gao Y, Wang G, Song G, Liu S, Sun D, Xu Y, Tian Z (2020a) Functional exhaustion of antiviral lymphocytes in COVID-19 patients. Cell Mol Immunol 17:533-535. https://doi.org/10.1038/ s41423-020-0402-2

Zheng YY, Ma YT, Zhang JY, Xie X (2020b) COVID-19 and the cardiovascular system. Nat Rev Cardiol 17:259-260. https://doi.org/ 10.1038/s41569-020-0360-5

Zhou J, Xu N, Wang ZL (2006) Dissolving behavior and stability of $\mathrm{ZnO}$ wires in biofluids: a study on biodegradability and biocompatibility of $\mathrm{ZnO}$ nanostructures. Adv Mater 18:2432-2435. https://doi.org/10.1002/adma.200600200

Zhou P, Yang XL, Wang XG, Hu B, Zhang L, Zhang W, Si HR, Zhu Y, Li B, Huang CL, Chen HD, Chen J, Luo Y, Guo H, Jiang RD, Liu MQ, Chen Y, Shen XR, Wang X, Zheng XS, Zhao K, Chen QJ, Deng F, Liu LL, Yan B, Zhan FX, Wang YY, Xiao GF, Shi ZL (2020a) A pneumonia outbreak associated with a new coronavirus of probable bat origin. Nature 579:270-273. https://doi. org/10.1038/s41586-020-2012-7

Zhou Y, Jiang X, Tong T, Fang L, Wu Y, Liang J, Xiao S (2020b) High antiviral activity of mercaptoethane sulfonate functionalized $\mathrm{Te} /$ BSA nanostars against arterivirus and coronavirus. RSC Adv 10(24):14161-14169

Ziaie S, Koucheck M, Miri MM, Salarian S, Shojaei S, Haghighi M, Sistanizad M (2020) Review of therapeutic agents for treatment of COVID-19. J Cell Mol Anesth 5:32-36. https://doi.org/10. 22037/jcma.v5i1.29760

Ziem B, Rahn J, Donskyi I, Silberreis K, Cuellar L, Dernedde J, Keil G, Mettenleiter TC, Haag R (2017) Polyvalent 2D entry inhibitors for pseudorabies and African swine fever virus. Macromol Biosci 17:1600499. https://doi.org/10.1002/mabi.201600499

Zodrow K, Brunet L, Mahendra S, Li D, Zhang A, Li Q, Alvarez PJJ (2009) Polysulfone ultrafiltration membranes impregnated with silver nanoparticles show improved biofouling resistance and virus removal. Water Res 43:715-723. https://doi.org/10.1016/j. watres.2008.11.014

Zolnik BS, González-Fernández A, Sadrieh N, Dobrovolskaia MA (2010) Minireview: nanoparticles and the immune system. Endocrinology 151:458-465. https://doi.org/10.1210/en.2009-1082 